
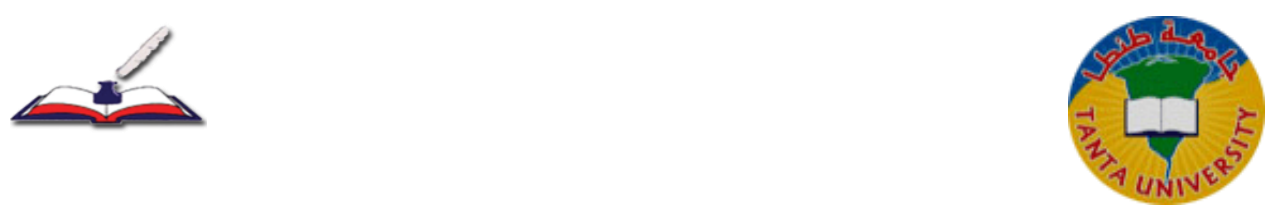

صورة الأثخاص ذوي الاحتياجات الخاصة في الأفلام التليفزيونية السينمائية المصرية ( دراسة ميدانية )

إعداد

د/ أميرة صابر محمود احمد

مدرس الأذاعة والتلفزيون بكلية التربية النوعية - جامعة طنطا ماحما

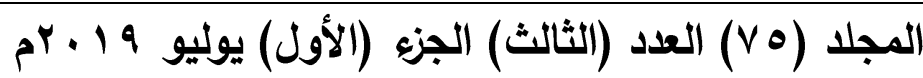


مقدمة

منذ سنوات عديدة والجهود الدولية متواصلة من أجل مواجهه احتياجات اصحاب

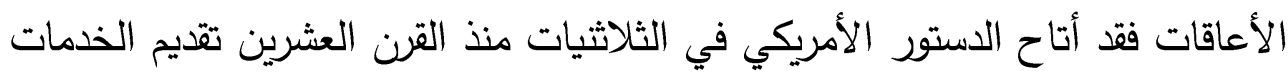

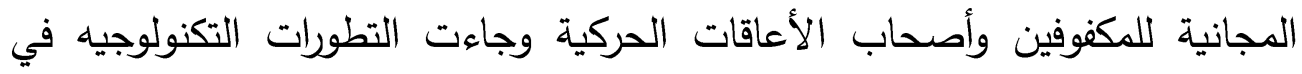

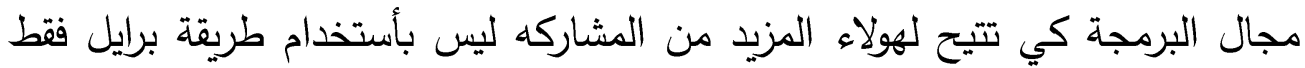

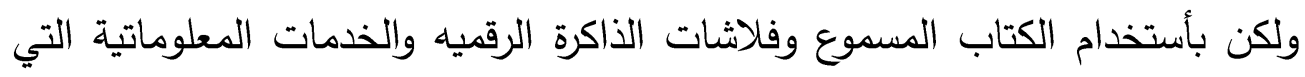

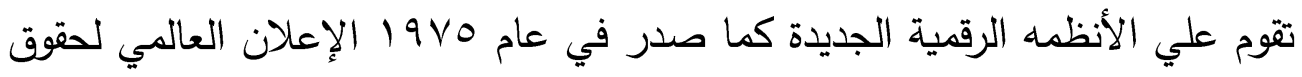

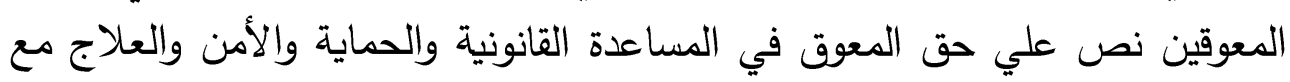

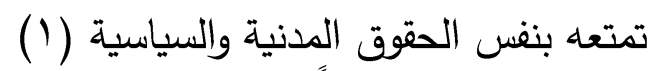
يوجد في مصر طبقا لأخر الأحصائيات التي صدرت في الجهاز المانية المركزي للتعبئة

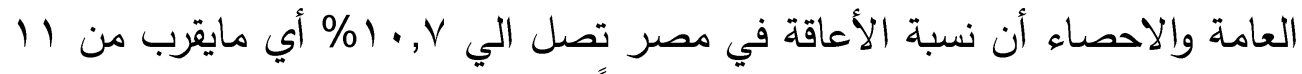

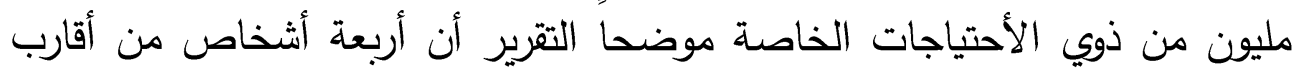

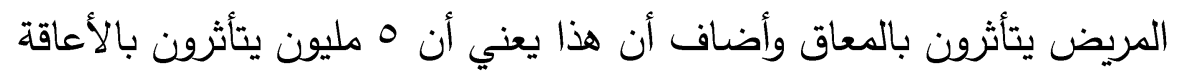

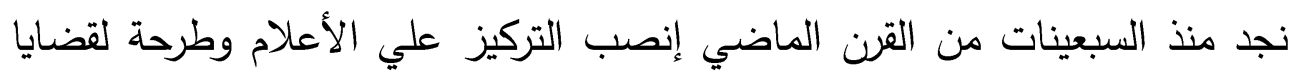

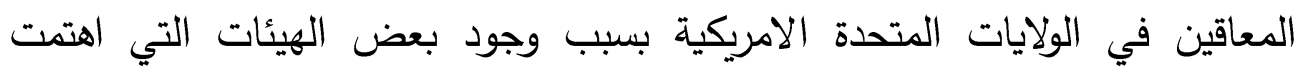

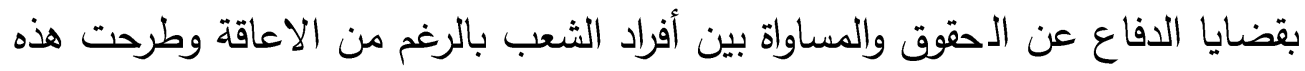

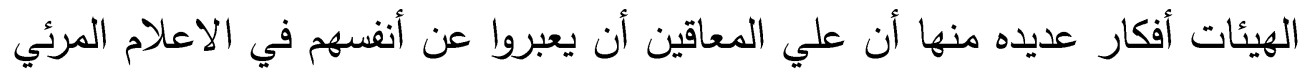

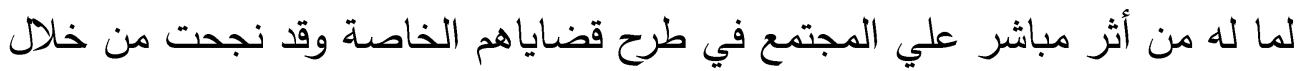

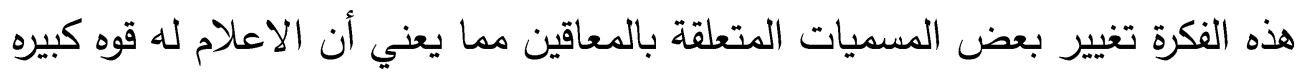

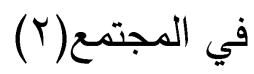

أثتبت دراسات كثيرة أن الإعلام يعد أهم المؤسِاتٍ الثقافيه والاجتماعيه المؤثره في

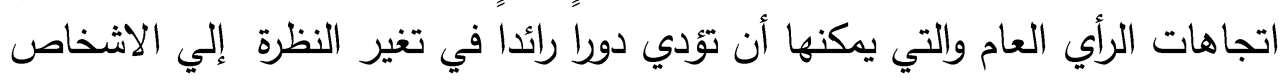

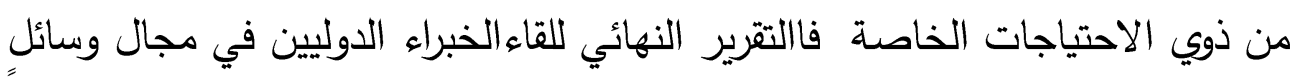

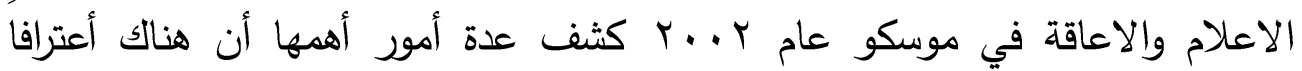

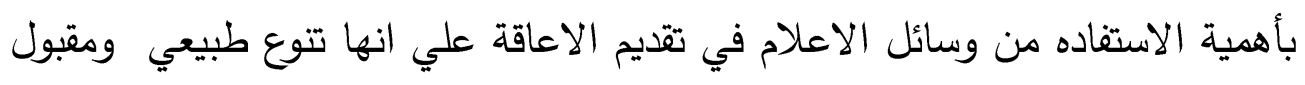

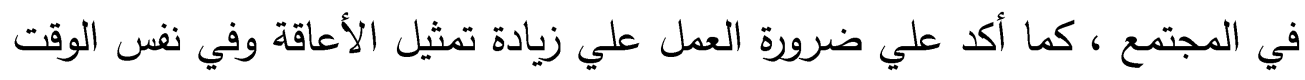

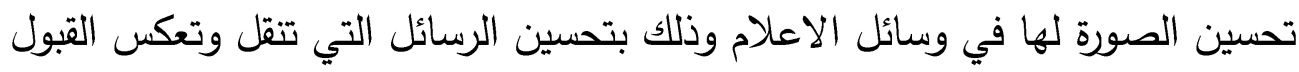

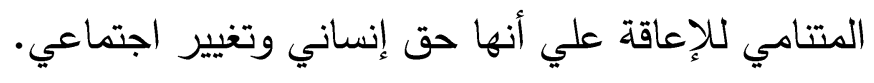

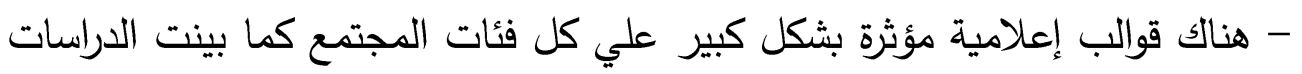

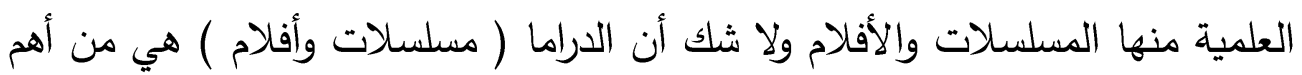


وأخطر القوالب الاعلامية لأن لها جاذبيه وإنتشارا بين المشاهدين والمستمعين كما

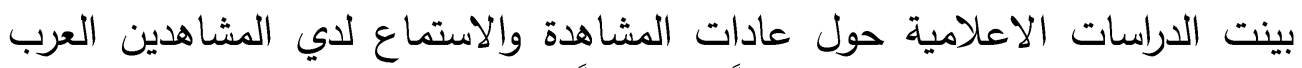

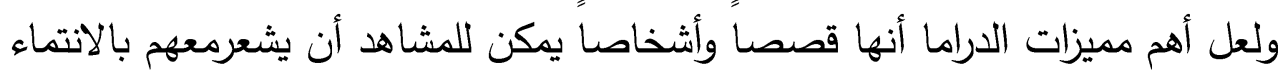

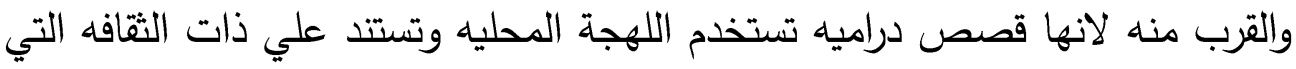

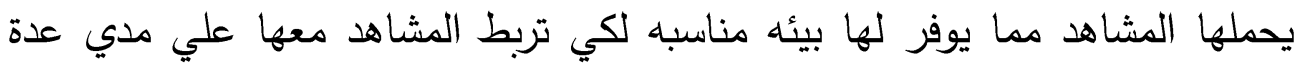

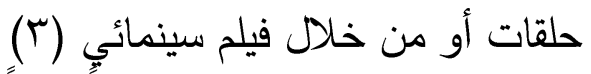
- من الملاحظ أن هناك قصورا كبيرا لطريقة تناول الدراما العببية لموضوع المعاقين

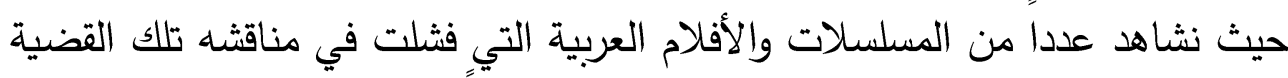

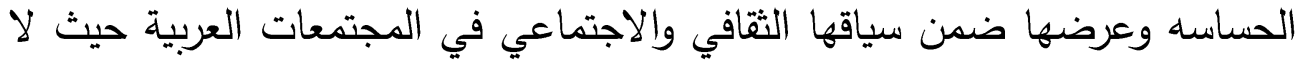
تخرج طرق المعالجه عن ثناث طرق للتعامل

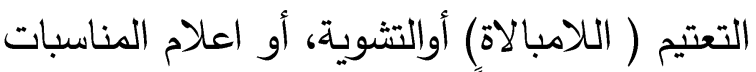

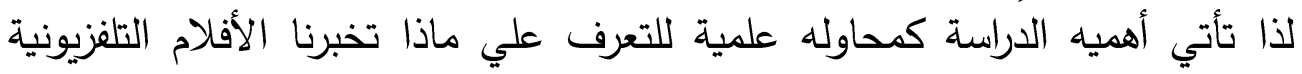

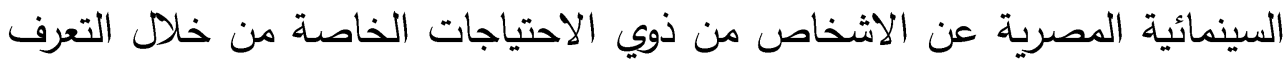

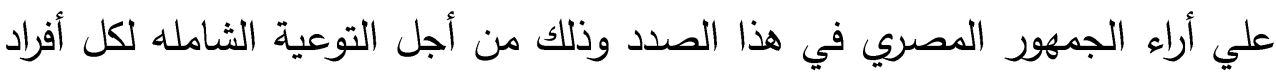

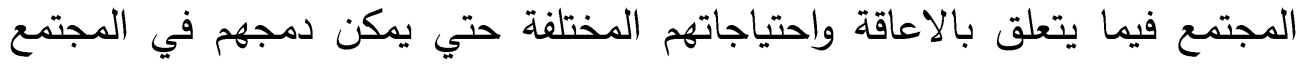
حتي يكونوا أعضاء فاعلين

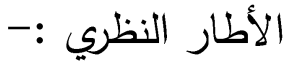
تعد نظرية الغرس الثقافي مفيدة ونحن نتحدث هنا عن العلاقه بين الاعلام والاعاقة وهي نظرية قدمها جرنبر

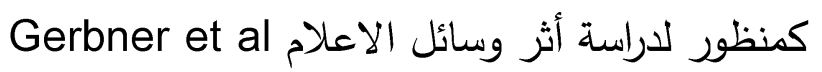

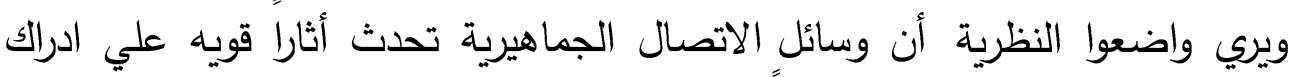

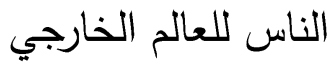
خاص هؤلاء الذين يتعرضون لتلك الوسائل لفترات طويلة ومنتظمه

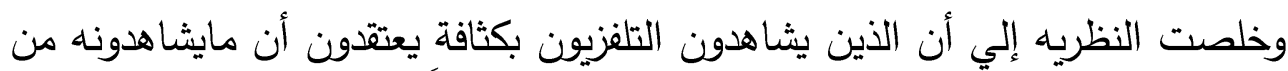

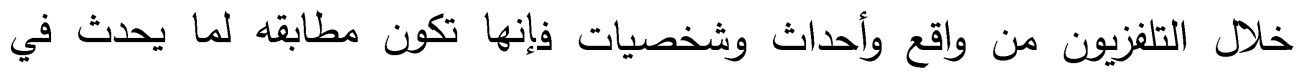

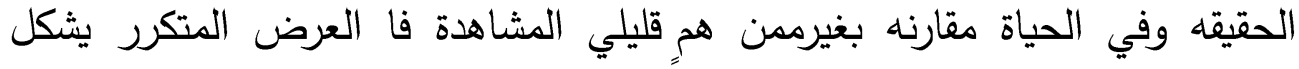
الاراء ويني المواقف كذلك المشاهدة المتكرة تخلق ثقافة موحده للحقيقه والاعتقادات

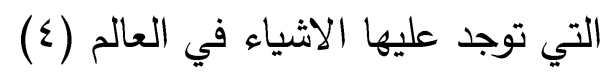

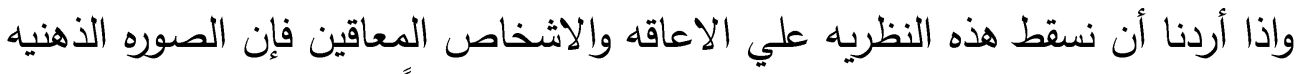
والواقع الاجتماعي التي تقدمه وسائل الاعلام ( وخصوصا التليفزيون ) عن المعاقين 
تجعل الجمهور سوف يؤمن بأن هذا الواقع الفعلي للمعاقين، فمثلا إذا كانت صورة

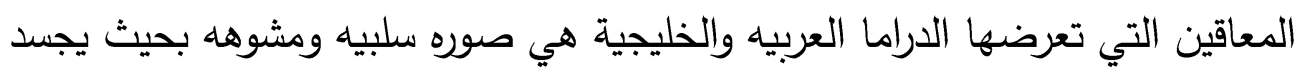

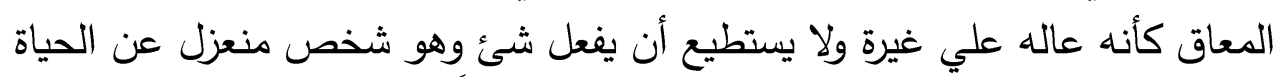
فإن مشاهدي التلفزيون عندما يشاهدون شخصا معاقاً أمامهم في الحياه العاه العامة فإنهم

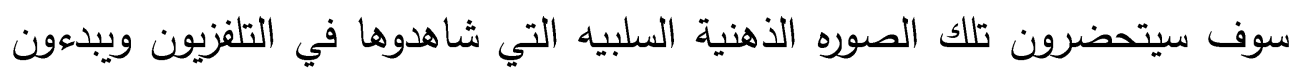

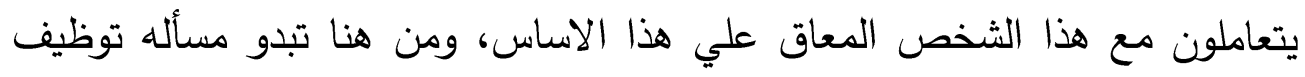

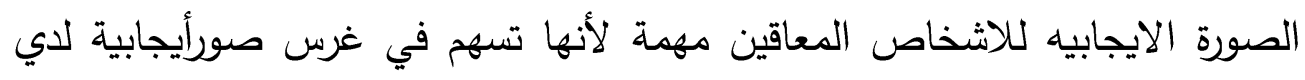
جمهور وسائل الاعلام وخاصة التلفزيون وبالتالي يبدأ الجمهور يغير من نظئ نظريتة السلبيه للمعاق الاعاقة والتتمية المستدامة ترعي التمية المستدامة الثخص المعاق باعتباره طاقة بشرِية معطلة تحتاج الي

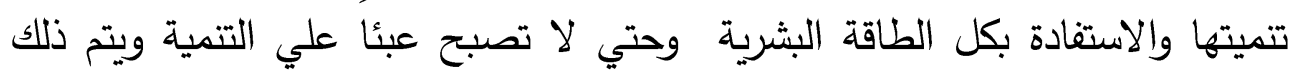

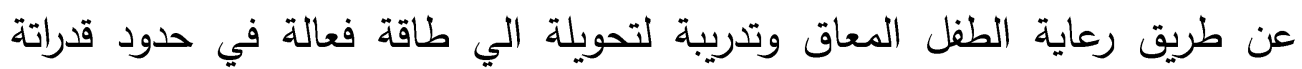

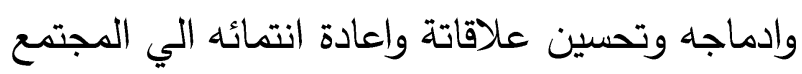

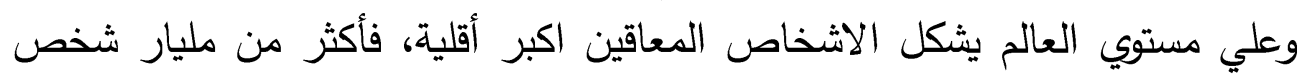

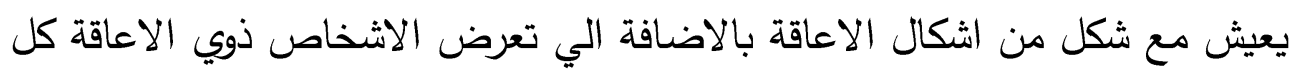

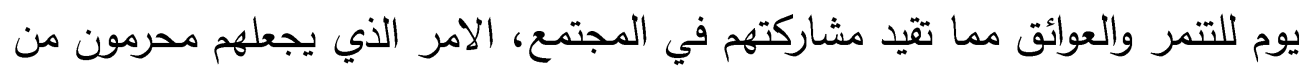

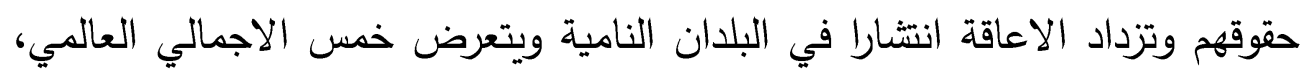

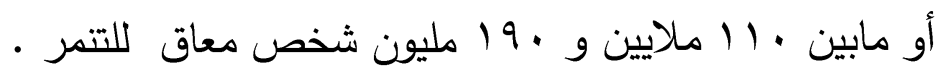

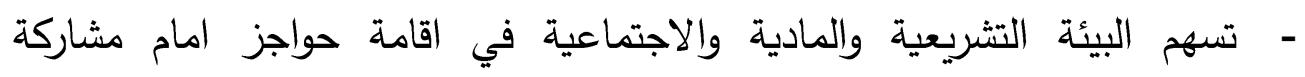

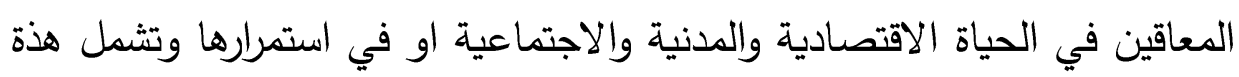

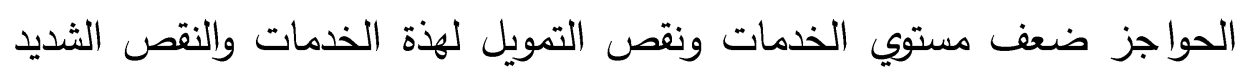

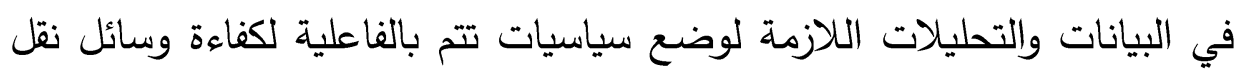

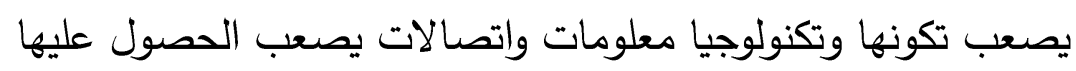

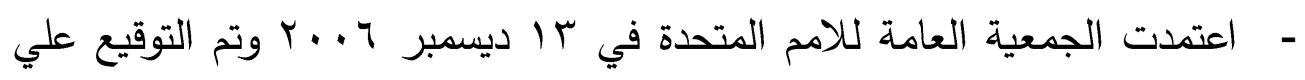

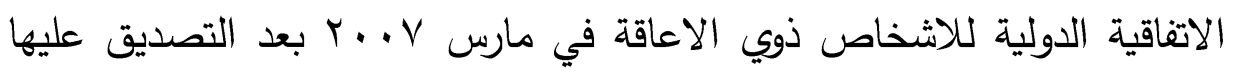

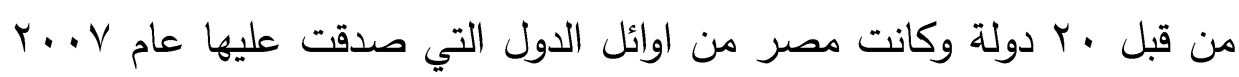

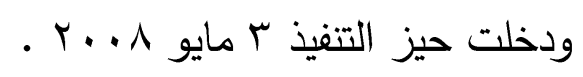

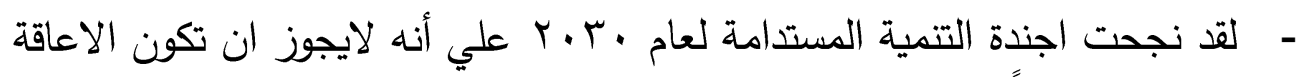

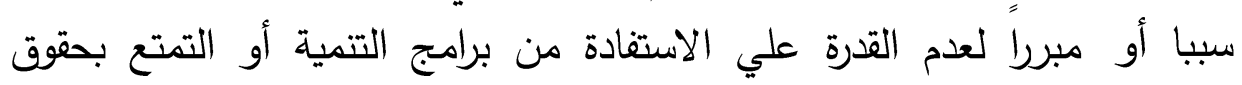


الانسان كما اشتملت الاجندة علي سبعه اهداف تشير صراحة الي المعوقين

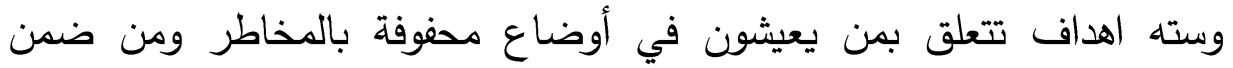
اهداف التنمية المستدامة مجالات التتمية الاساسية مثل التعليم و العمالة والحماية الاجتماعية والصرف الصحي والقدرة علي مواجهة الكوارث والتخفيف من أثارها

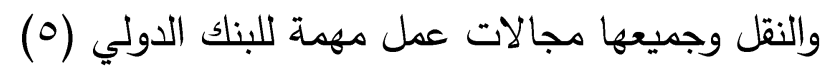

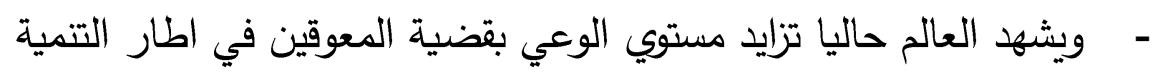

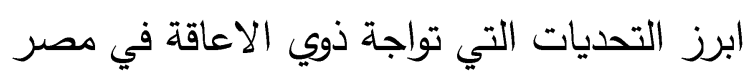

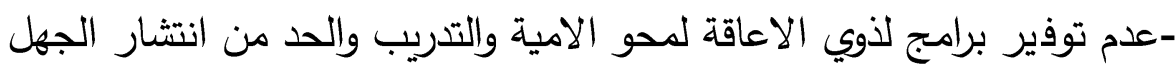

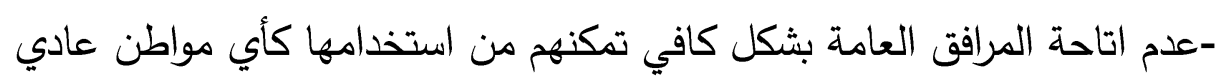

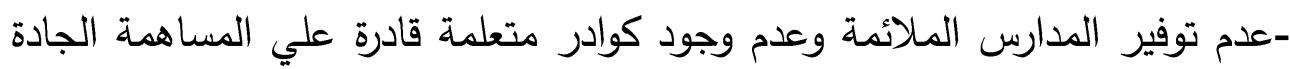
في البناء

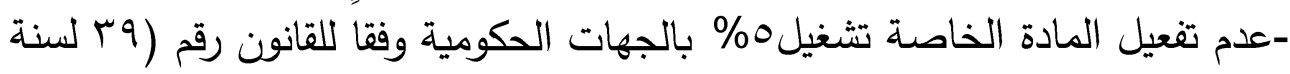

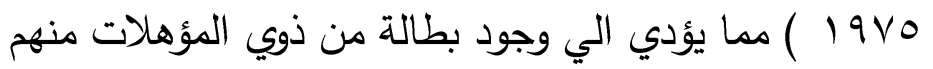

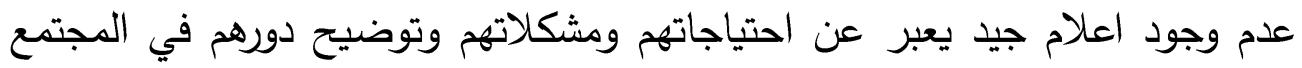

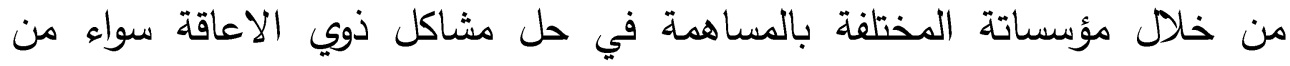
الاحزاب ومؤسسات المجتمع المدني ووزارت التعليم والصحة والسكان والثئن الاجتماعية والمالية والتخطيط وغيرها من الوزارات المختلفة قانون الاعاقة الجديد ومكتسباتة المنتظرة لم يفعل الجانب التشريعي حقوق المعاقين في مصر ورعايتهم

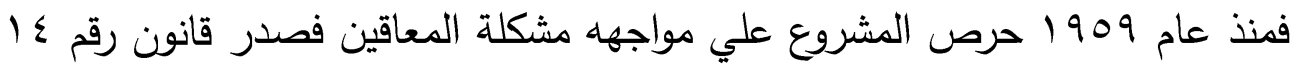
لسنة 1909 بثأن التأهيل المهني للعاجزين عن العمل ثم عادئه ماد المشروع مرة ثانية

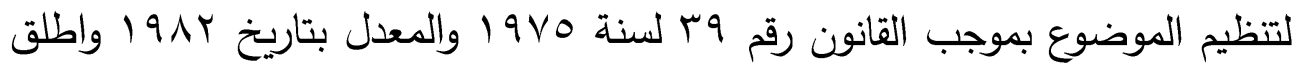

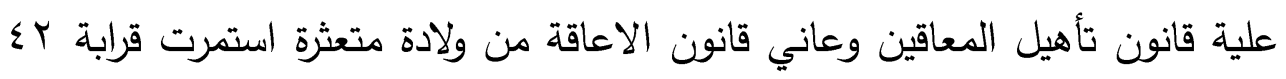

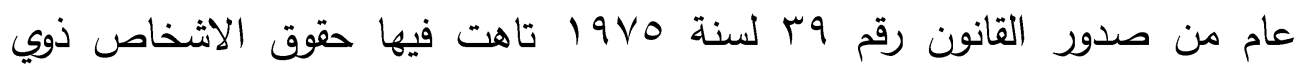

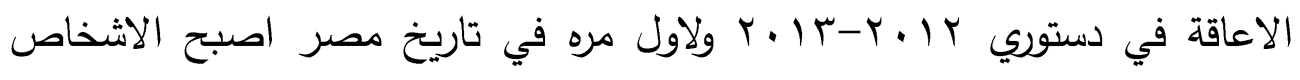

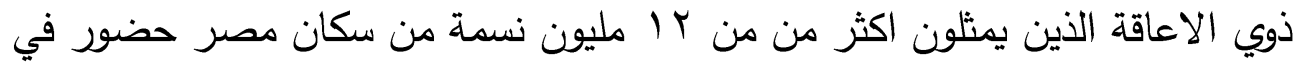

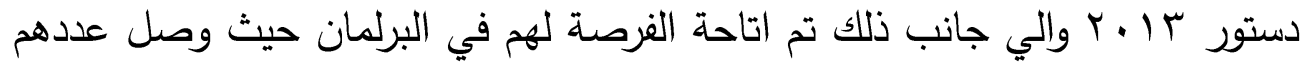
الي 10 أني

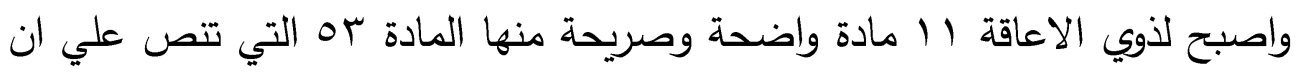

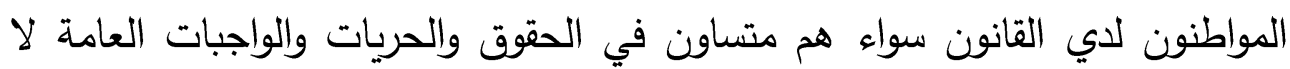


يميز بينهم الدين أوالعقيدة أواللون أواللغة أوالاعاقة مما ضمن القانون حقوق المعاقين

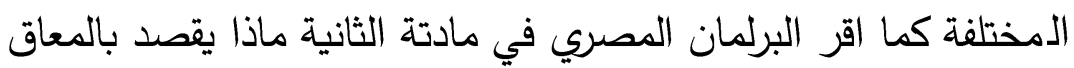

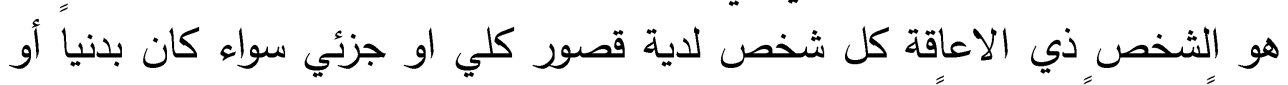

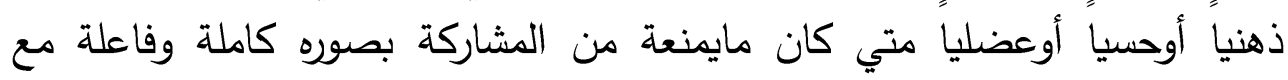

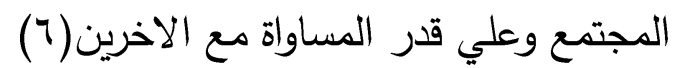
مكتسبات الاشخاص ذوي الاعاقة من القانون الجديد يثكل القانون الجديد بارقة امل للاشخاص المعاقين وذويهم حيث حدد لقانون عدة لاعن

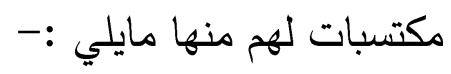
الرعاية :- تقديم الخدمات اللازمة للاشخاص ذوي الاعاقة بما يتاسب مع نوع ودرجة مدي استقرار اعاقتهم وظروفهم الاقتصادية والاجتماعية واحتياجاتهم وميولهم لاتها واختباراتهم وحقوقهم ملات التواصل :- ارسال واستقبال وتبادل وسائل الاتصال المناسبة بين الاشخاص ذوري الاعاقة وبعضهم وبينهم ومن غيرهم من غير ذوي الاعاقة واللغات مختلف اشكالها

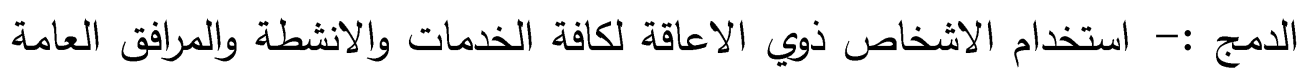
ووسائل التعلم علي قدم المساواه مع الاخرين في المجتمع دون اقصاء او استبعاد الاد الهاء التأهيل :- تمكين الثخص ذوي الاعاقة واسرتة من الدرجة الاولي من استعارة او تحقيق او تطوير قدراتة الجسمية أوالعقلية أو الذهنية أوالعصبية أوالاجتماعية

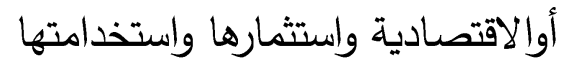
شهادات التأهيل :- الثهادة المنصوص عليها في المادة (1 I ) من هذا القانون تعطي للشخص ذو الاعاقة الذي تم تأهيلة ويدون له المهنه التي تم تأهيلة لها ودرجة تأهيلة ونوع ودرجة الخلل ولياقتة الصحية في شأن تلك المهنه التأهيل المجتمعي :- تأهيل الاشخاص ودهه ذوي الاعاقة وتمكينهم من ممارسة حقوقهم

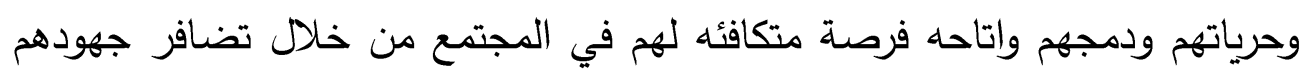
وأسرهم وافراد المجتمع ومنظماتة للمساعدة في هذا الاندماج

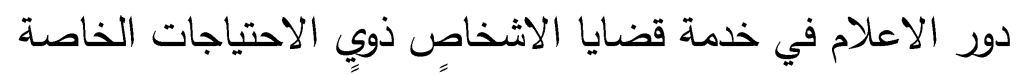

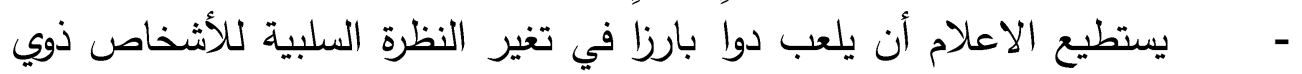

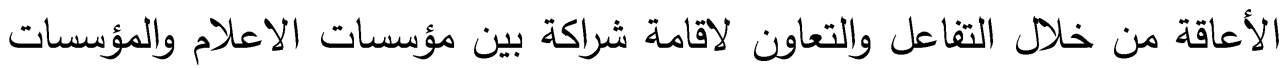
المهتمة بذوي الاحتياجات الخاصة تعمل علي تحقيق مايلي : ا- الانسان توعية الاعلامين بقضية الاعاقة بإعتبارها احدي القضايا المرتبطة بحقوق 
Y- تخطيط عده حملات أعلامية لخدمة قضايا ذوي الاحتياجات الخاصة ب- توثيق العلاقة مع مندوبي الاعلام ، حتي مع الاشخاص الذين قد يملكون اتجاهات سلبية نحو ذوي الاحتياجات الخاصة العاصة

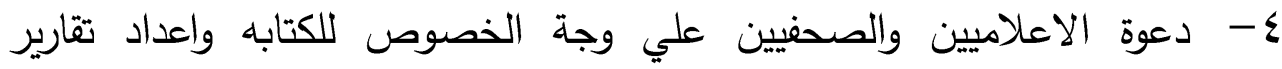
وتحقيقات صحفية علي موضوعات ذوي الاحتياجات الخاصة ولاتية

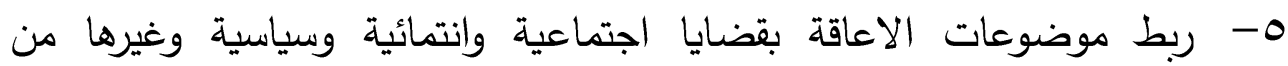

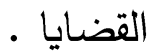

الدور الثاني للاعلام من خلال الوقاية من الاعاقة :- عن طريق الخطوات التالية:-

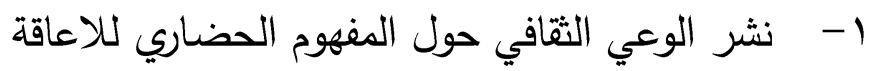

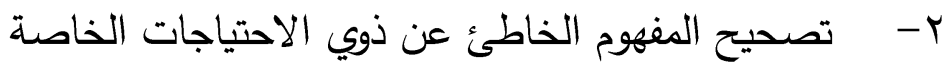

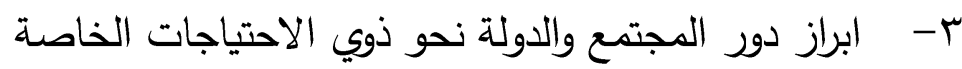

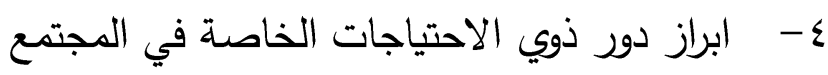
- - - توضيح حقوق ذوي الاحتياجات الخاصة في الثريعه والقانون 7- ابراز الانثطة الثقافية والاجتماعية والرياضية والفنية لذوي الاحتياجات الخاصة

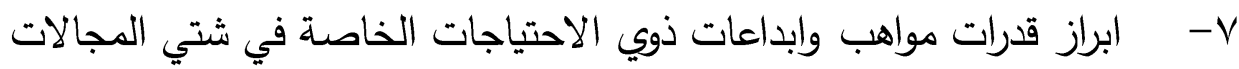

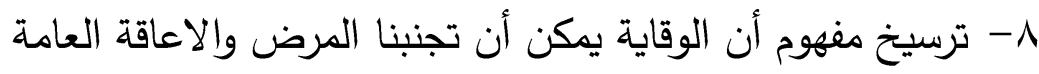

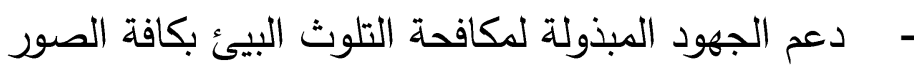

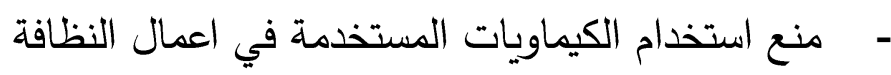

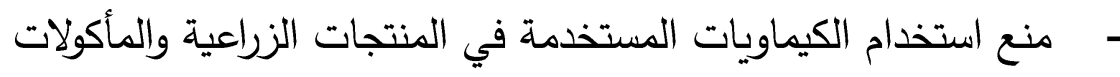

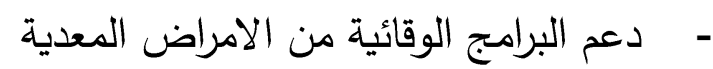

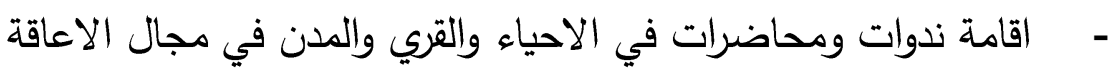

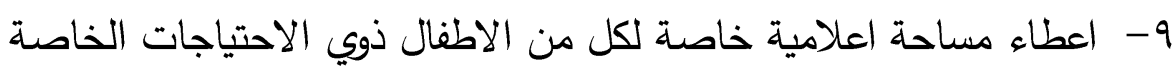
- - - اعلام متخصص في الاعاقة من خلال :-

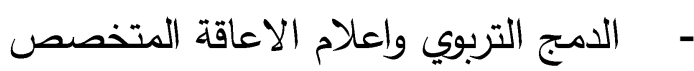
- - انشاء قناة واذاعه وصحف ومجلات متخصصة في الاعاقة وذي الاحتياجات الخاصة تسليط الضوء من خلال الاعلام علي النماذج الايجابية من خلال المعاقين الذين

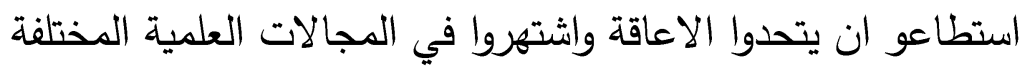




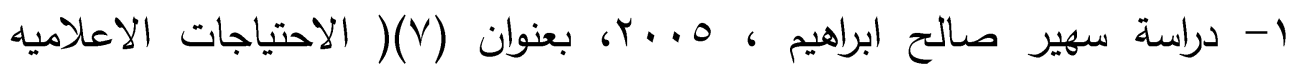

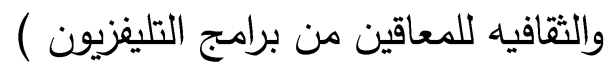
هدفت الدراسة الي التعرف علي الاحتياجات الاعلاميه والثقافيه للمعاقين من برامج

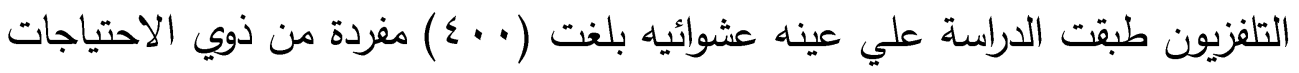

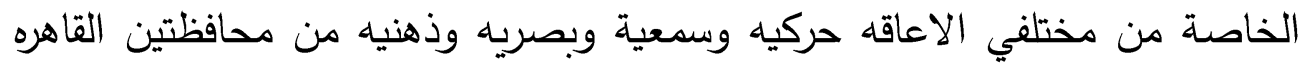

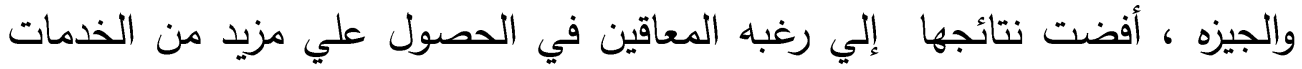

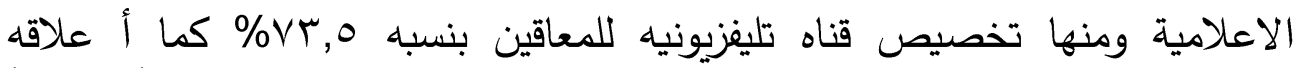

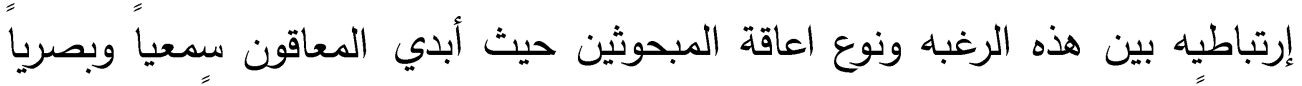

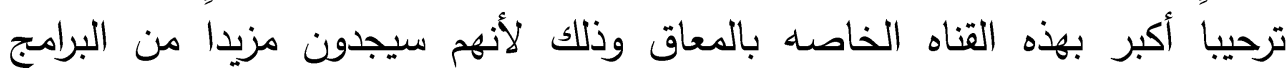
والخدمات التي تراعي أساليب الاتصال الحديثة في التعامل معهم من خلال مواد هذه القناة

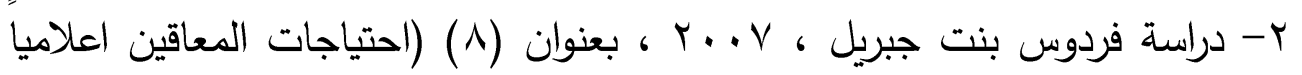

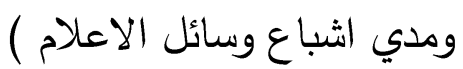

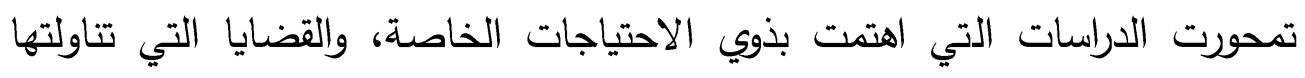

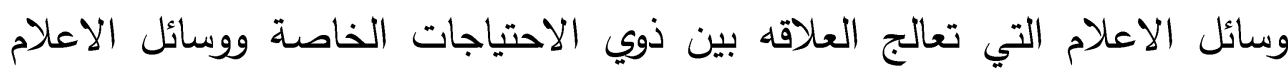

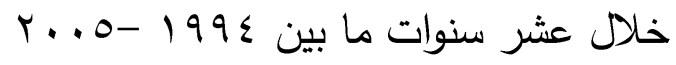

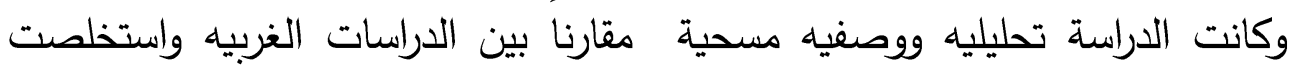

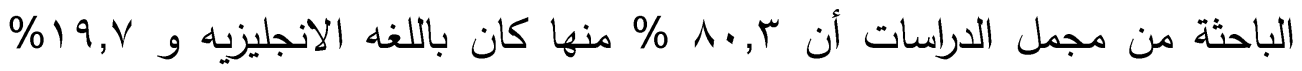

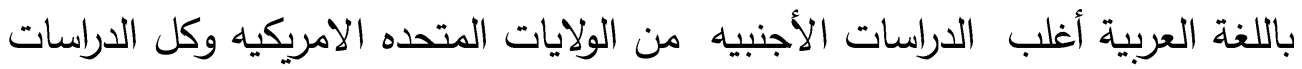

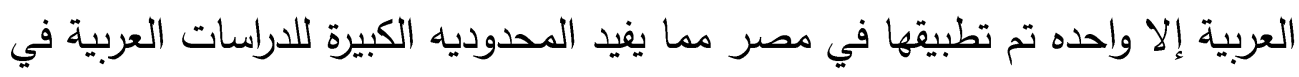
هذا المجال - الال

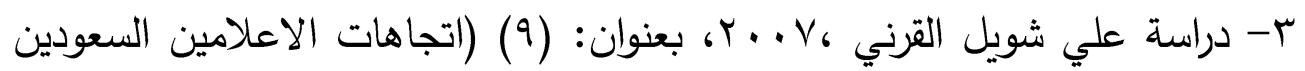

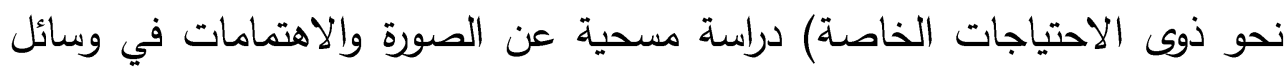

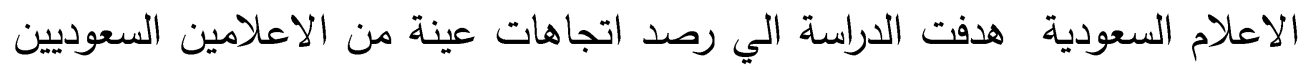

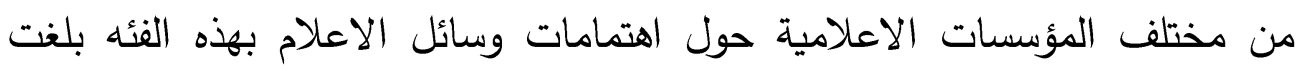
قوامها . . . مفرده من العاملين في مجال الاعلام إستخدمت الدراسة أداه الاستبيان

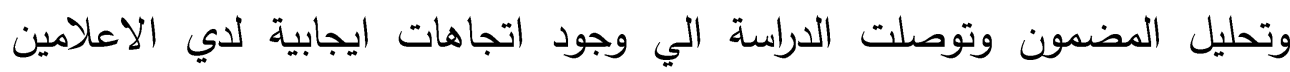
السعودين نحو المعاقين

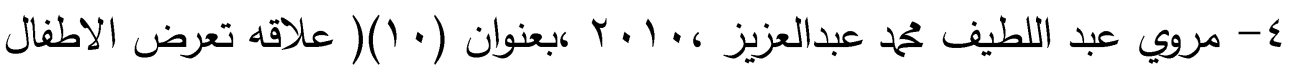

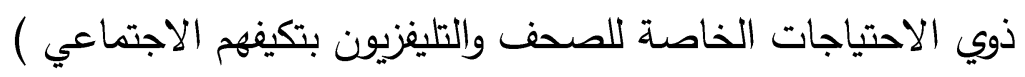




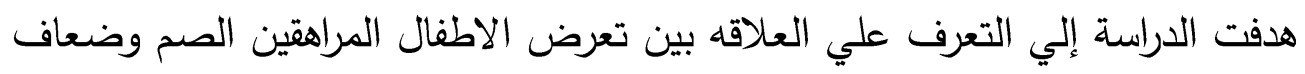

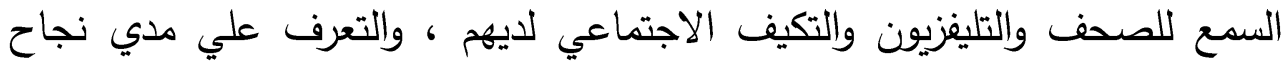

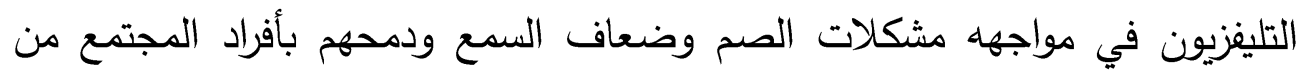

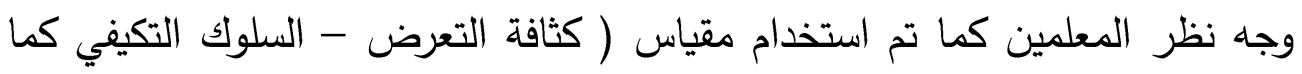

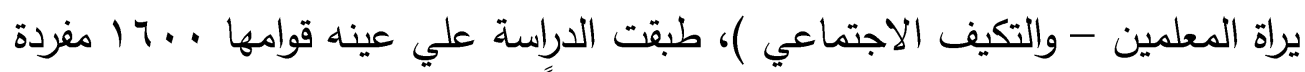

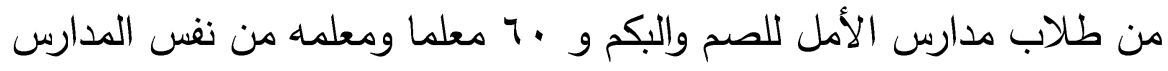

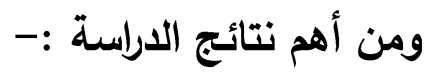

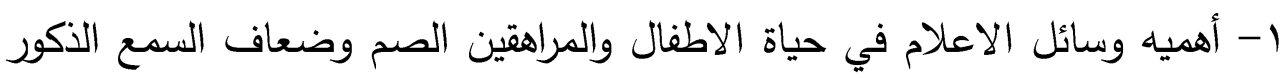

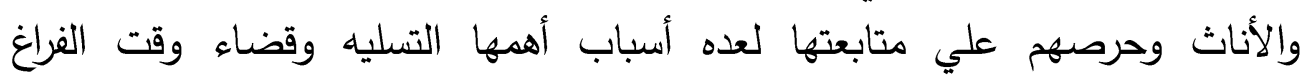

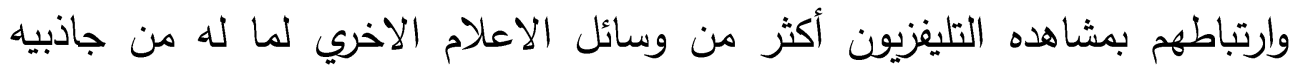
وتثويق r- جاء الاقبال علي مشاهدة الاغاني بالتليفزيون من جانب الاطفال والمراهقين الصم

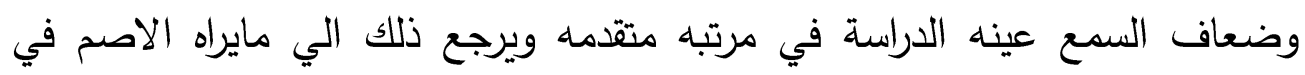

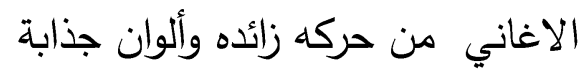

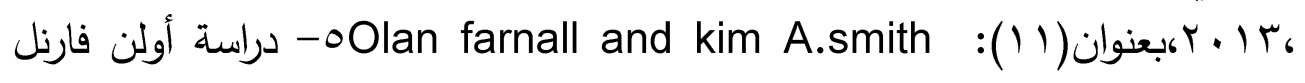
وكيم سميث ( ردود الافعال نحو أصحاب الاحتياجات الخاصة : الاتصال الثخصي مقابل

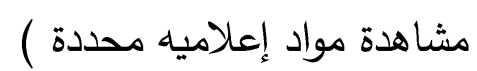

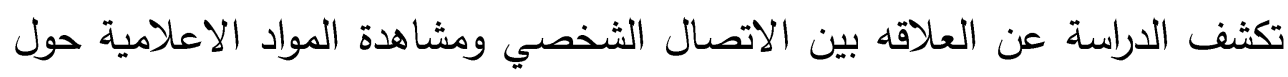

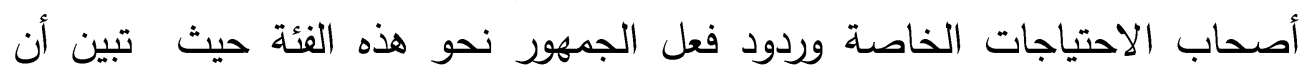

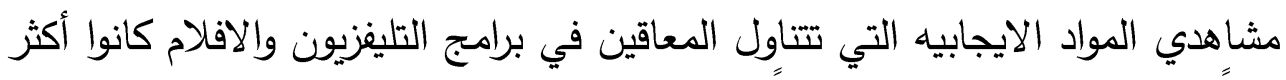

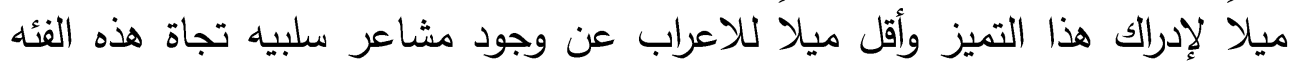

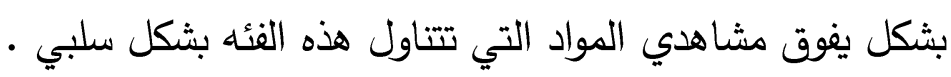

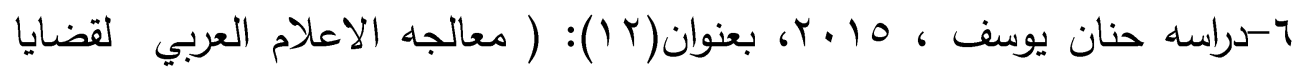

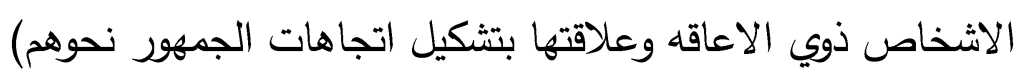

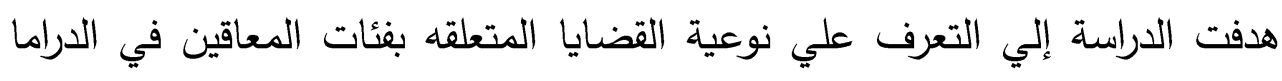

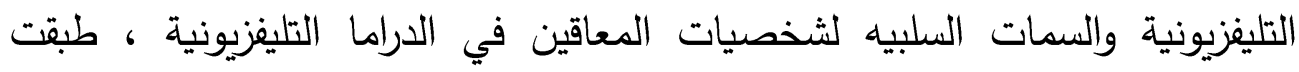

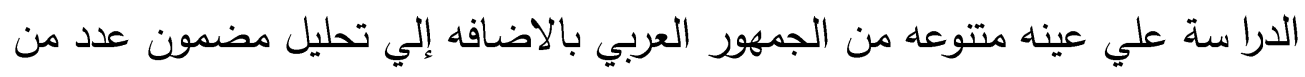

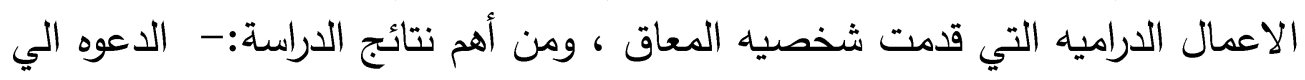

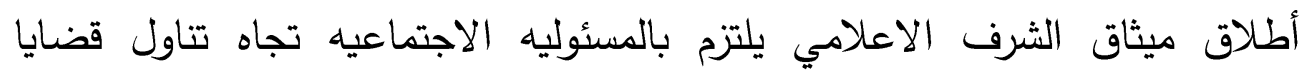


الاشخاص ذوي الاعاقه ودور الاعلام في تثكيل اتجاهات الجمهور نحوهم وضروره

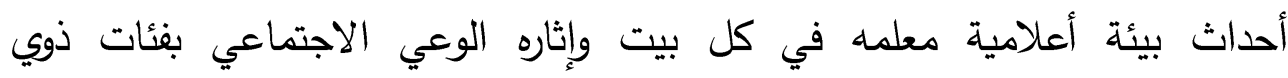

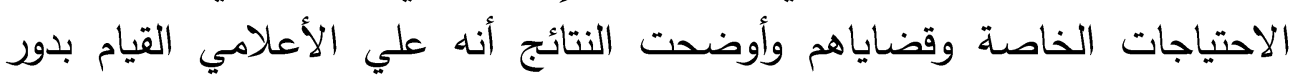

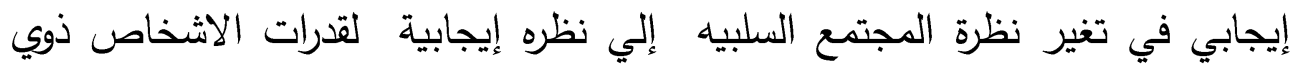

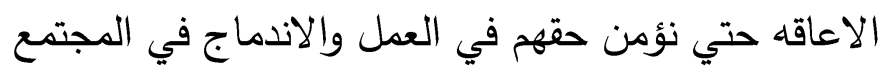

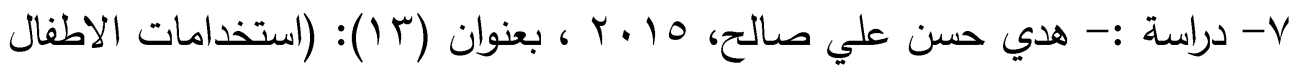

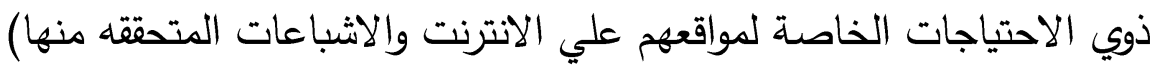

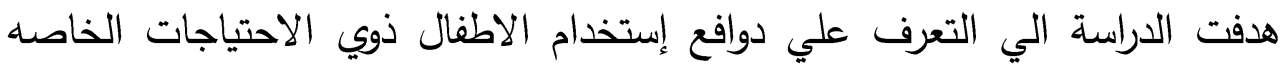

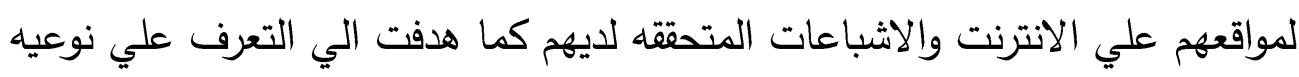

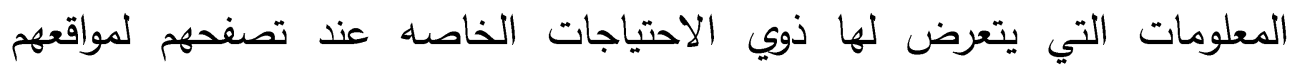
الالكترونيه

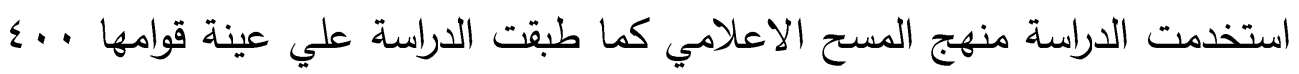

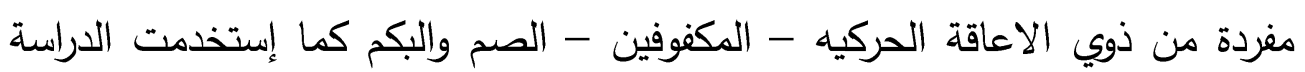

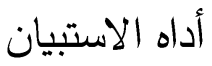

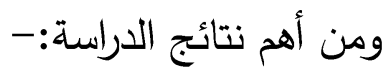

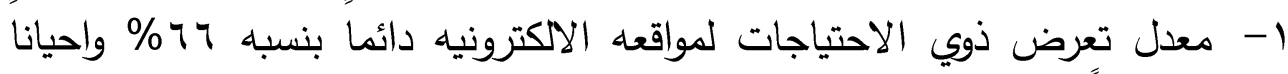

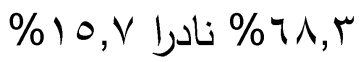

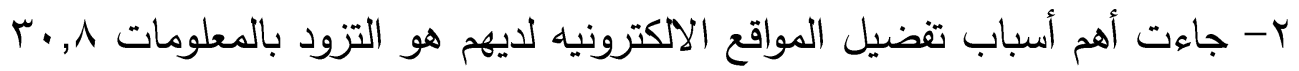

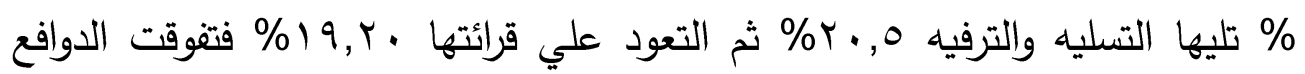
النفعيه علي الدوافع الطقوسية لديهم 0- دراسة رحاب سعيد احمد عبدالرحمن ( فاعليه فيلم رسوم متحركه باستخدام الوسائط المتعدة للاطفال ذوي الاحتياجات الخاصده ) r.IV

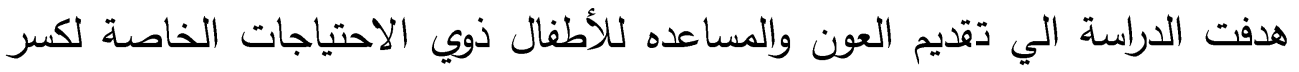

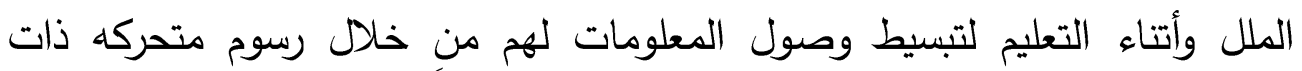

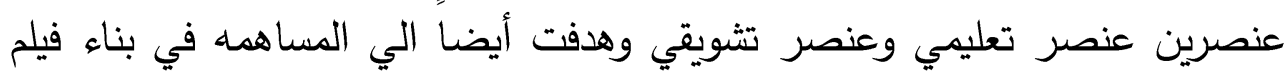

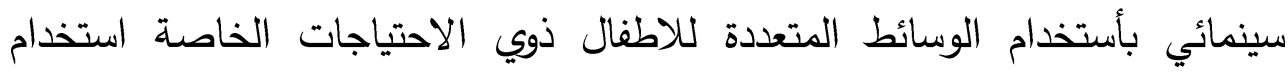

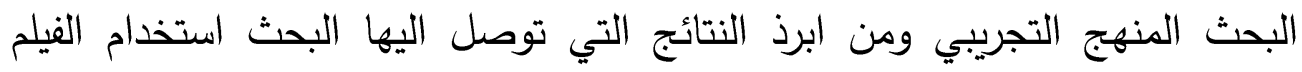

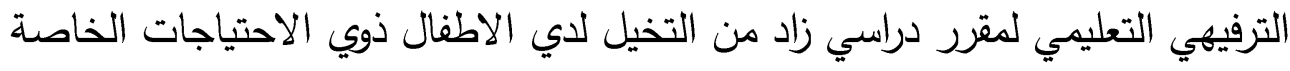

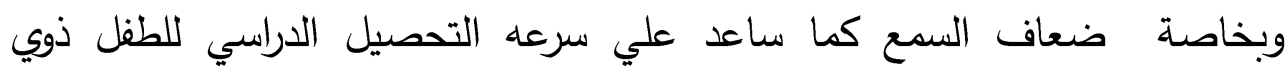

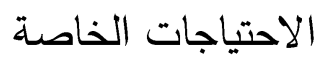




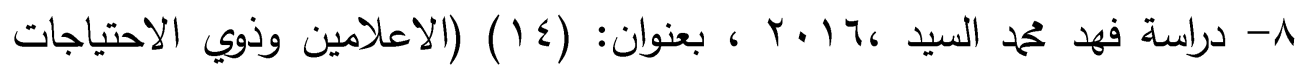
الخاصه بالمملكه العربيه السعوديه)

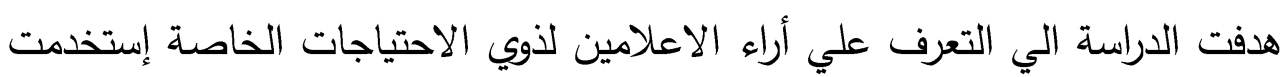

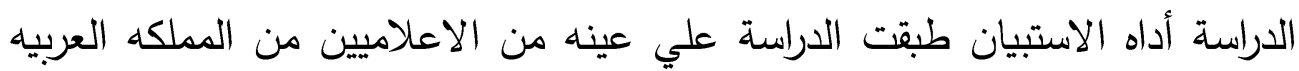

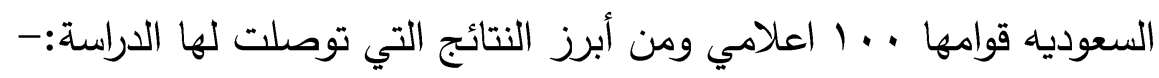

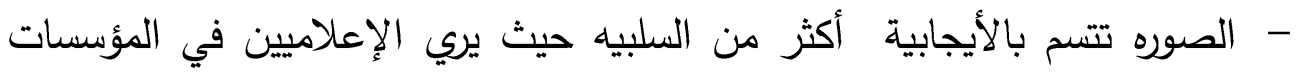

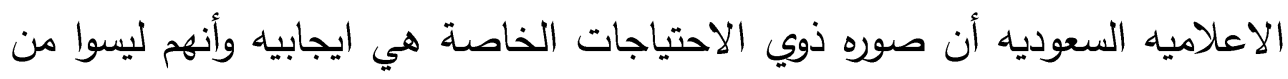

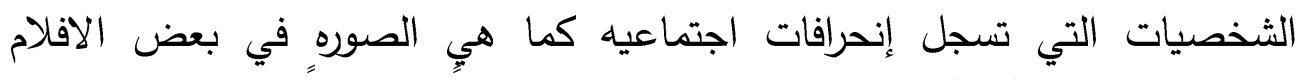

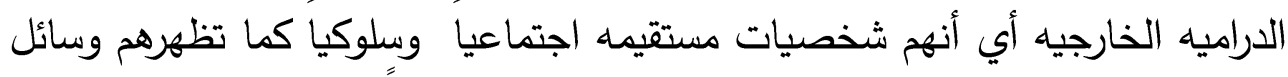

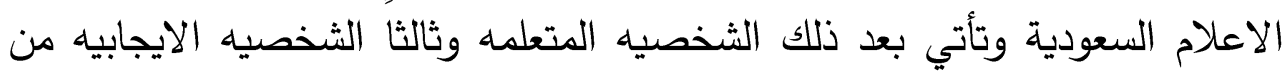

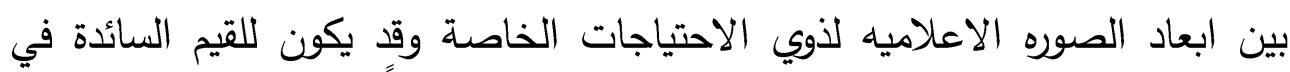

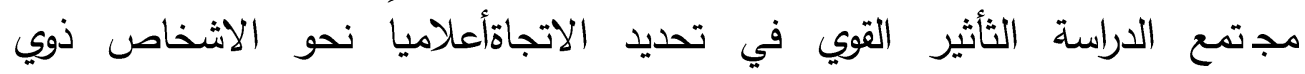
الاحتياجات الخاصة

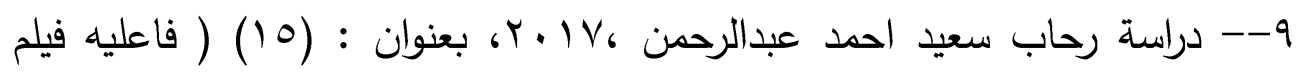

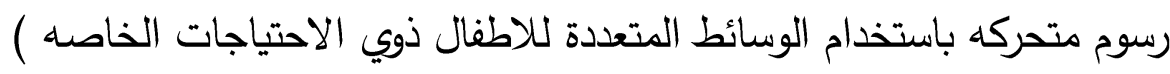

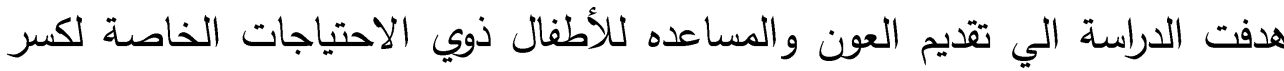

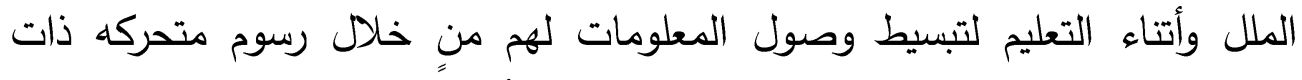

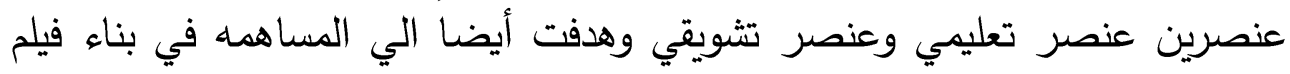

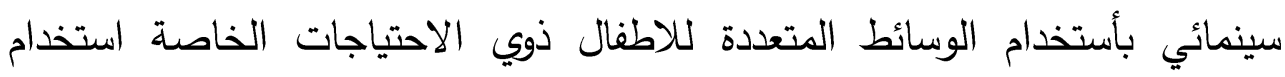

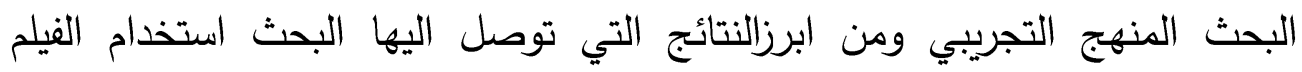

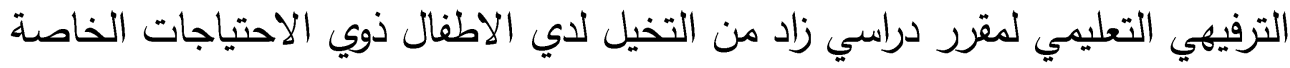

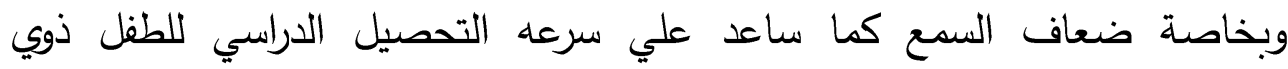
الاحتياجات الخاصة

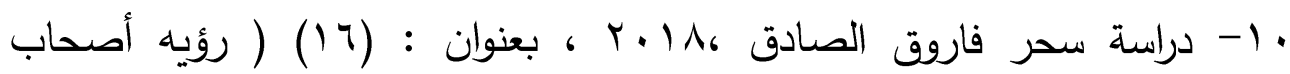

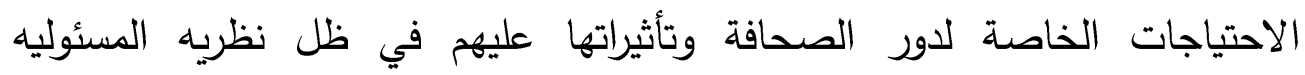

الاجتماعيه )

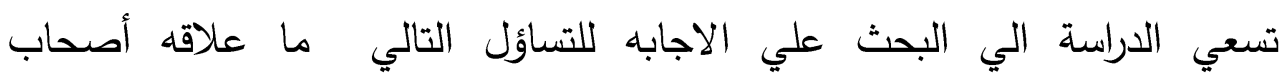

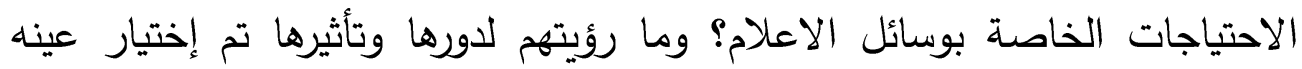

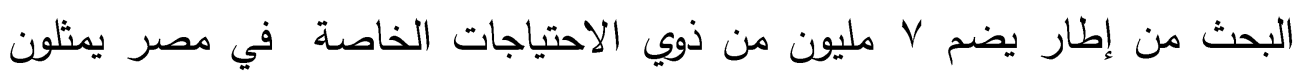

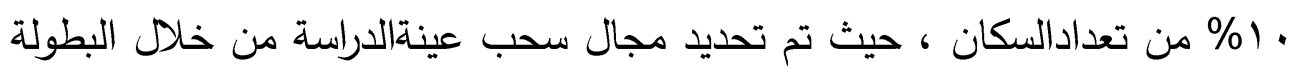


السادسة لمنتخبات المحافظات بجامعة حلوان من خلال عينة عشوائية من المشاركين

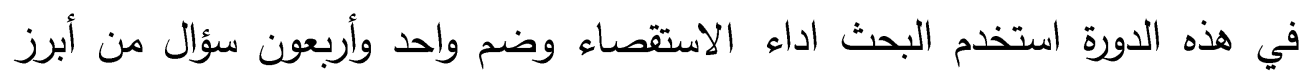

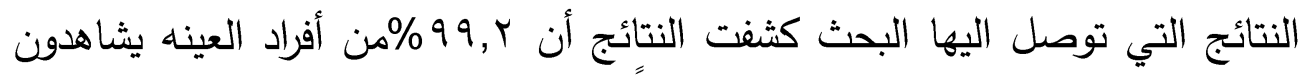

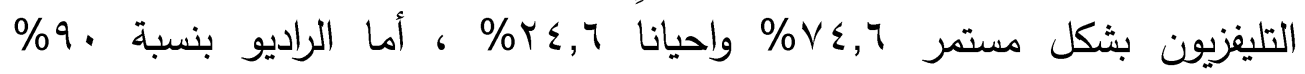

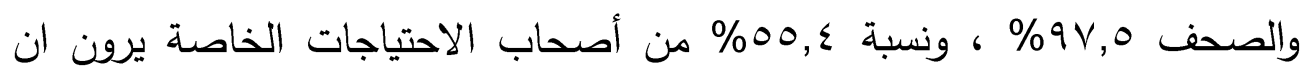

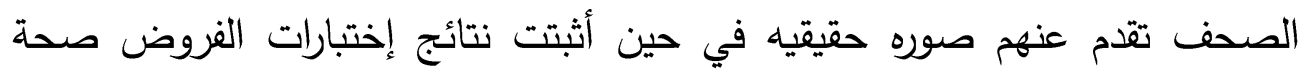

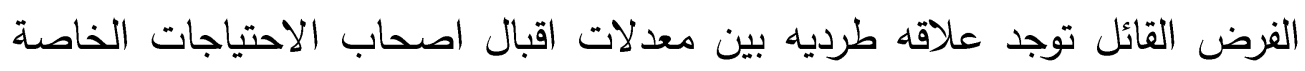
علي قراءة الصحف المختلفة ومعدلات تلبية الصحافة لاحتياجتهم المعرفيه التعليق علي الدراسات السابقة

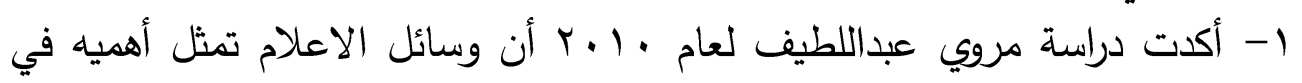

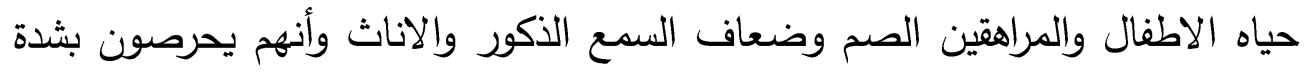

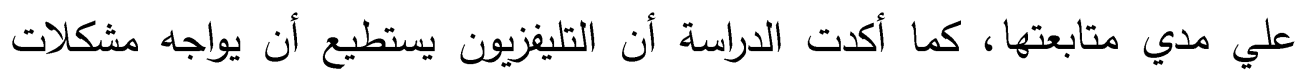

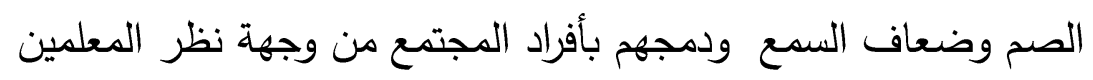

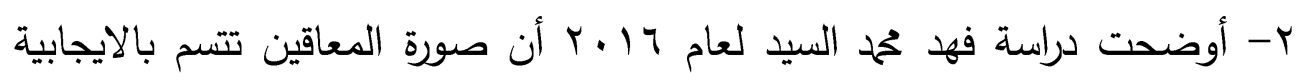
أكثر من السلبيه حيث يري الاعلامين في المؤسسات الاعلاميه السعوديه وأنهم ليسوا

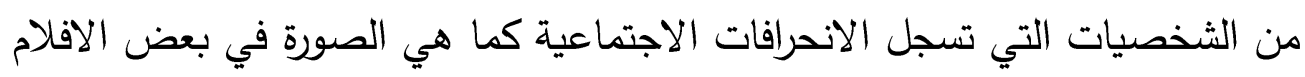

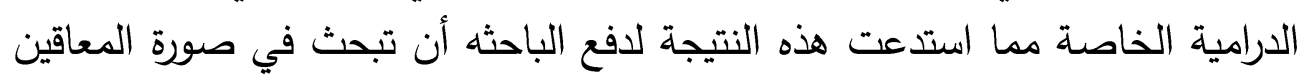
في الافلام التليفزيونية

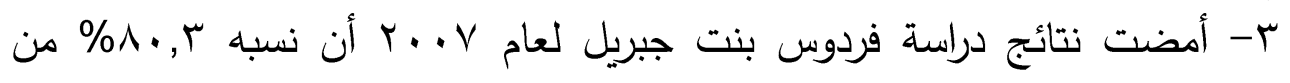

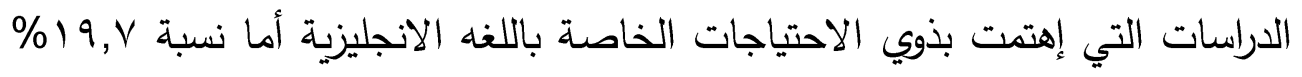

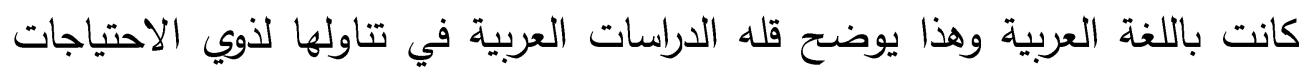
الخاصة

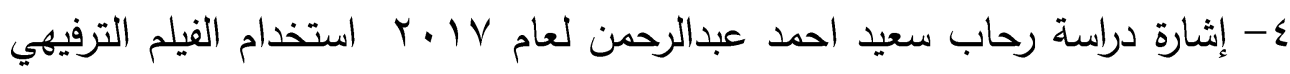

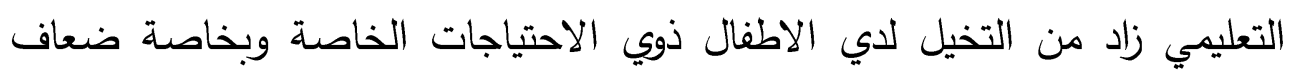

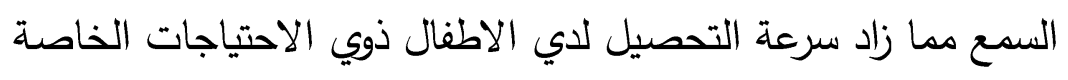

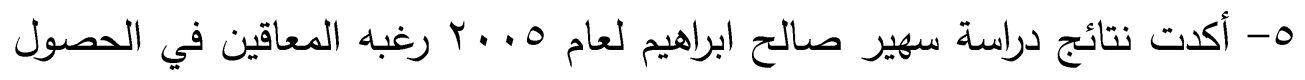

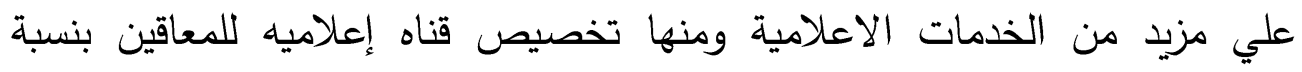
\%रr,

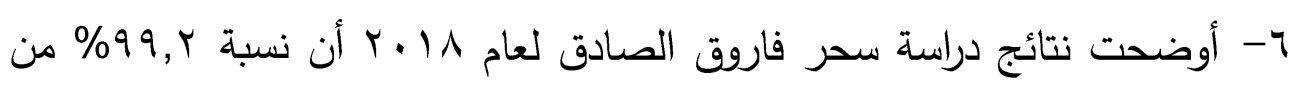
المعاقين يثاهدون التليفزيون بصفة دائمه دائه 
V أشارت نتائج دراسة أولين ولكيم أن مشاهدي المواد الايجابيه التي تتناول المعاقين

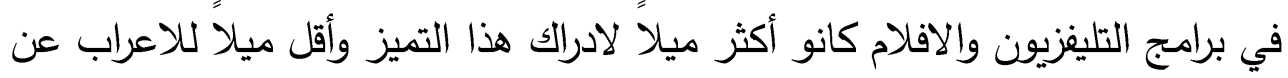
وجود مشاعر سلبيه تجاه هذه الفئه بثكل يفوق مشاهدي المواد التي تتناول هذه الفئه

$$
\text { مدي الاستفاده من الدراسات السابقة }
$$

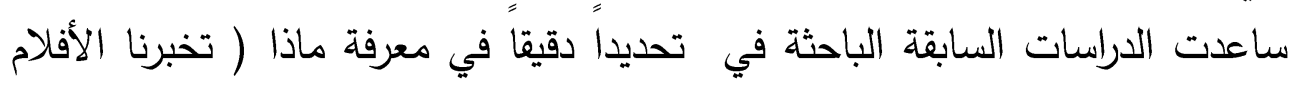

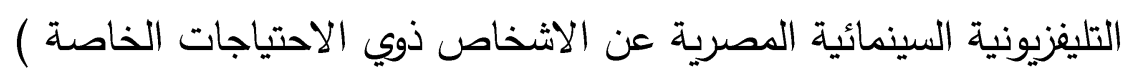

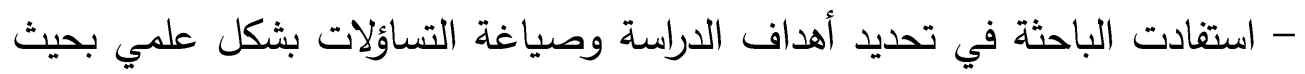

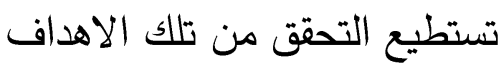
- في المنهج المستخدم حيث استخدمت الباحثة المنهج الوصفي الذي يعبر عن الاهن

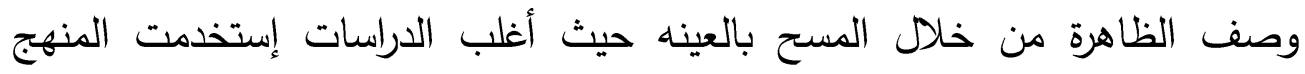
التجريبي والمقابلات وتحليل المضمون مما دفع الباحثة أن تستخدم أداة الاستبيان

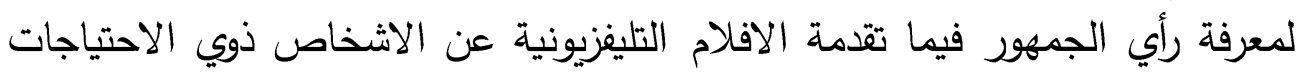
الخاصة

- سوف يتم المقارنة بين نتائج الدراسة الحالية والنتائج التي توصلت اليها الدراسات

في ظل التطورات المتسارعه في مختلف حقول الاعلام والتي بات من الصعب معها

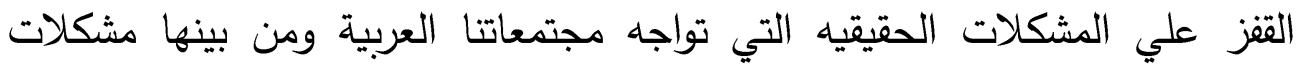
(الفئات الخاصة) ولعل من بين اهم تلك المشكلات والتي بدأت بالأزدياد ككرة التلج التهات

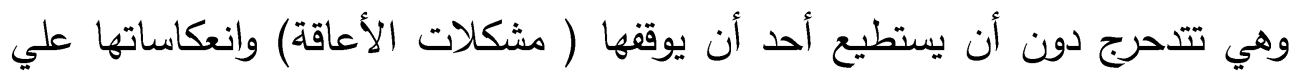

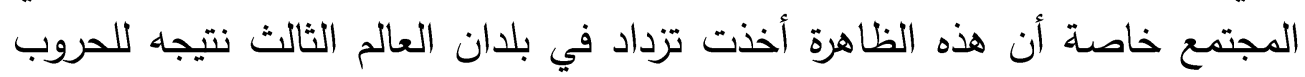

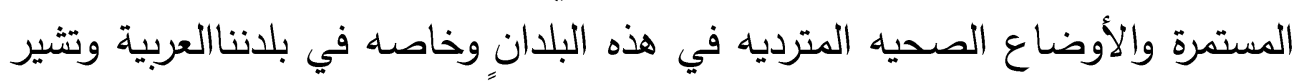

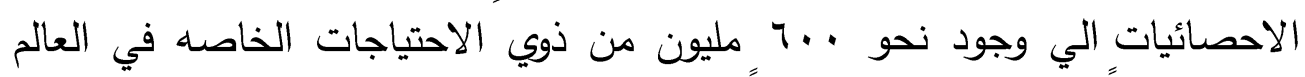

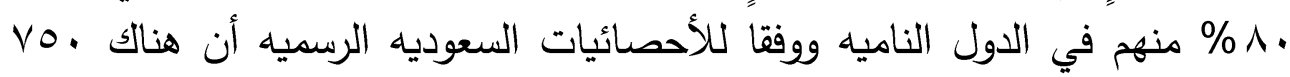

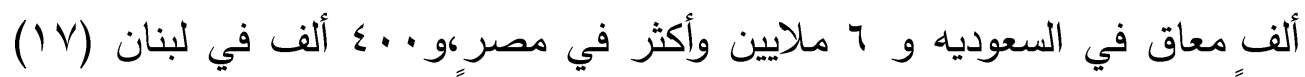

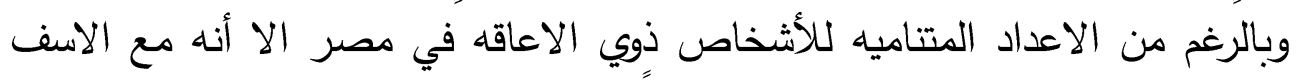

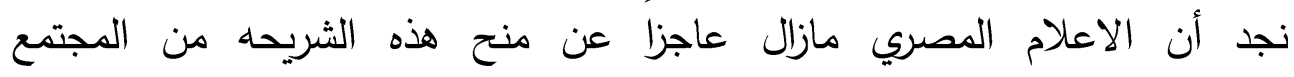


الاهتمام الكافي في حين حاولت الدراما التلفزيونية المصريه إستغلال الاعاقه سلبياً من

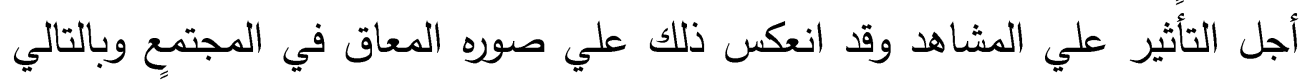

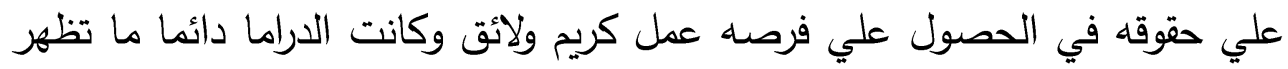

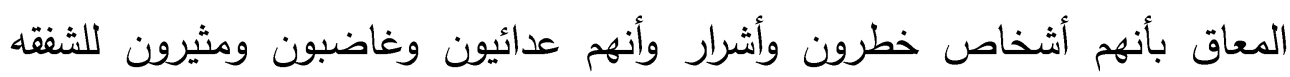

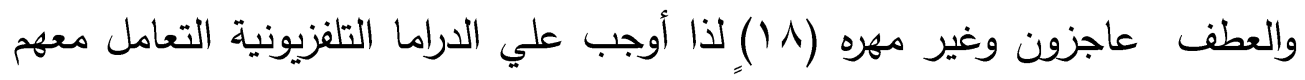

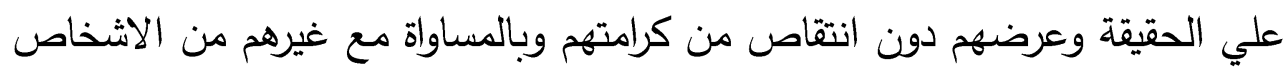

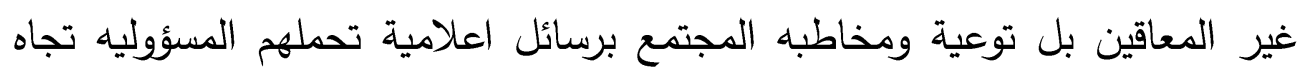

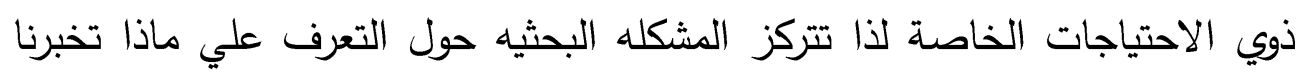

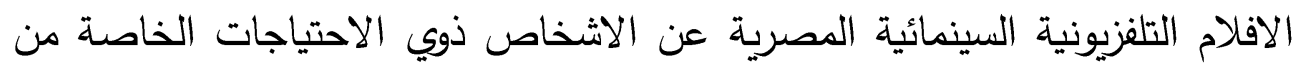

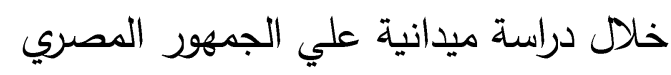

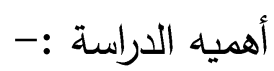

1- تأتي أهمية الدراسه من أهمية الافلام التليفزيونيه حيث تعد شكل من أثكال الدراما

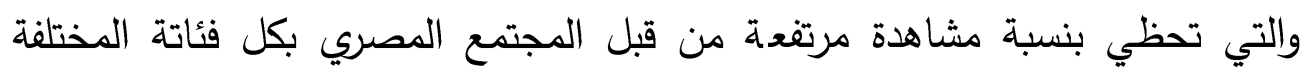

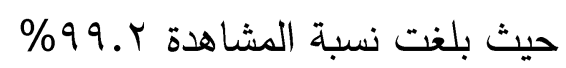

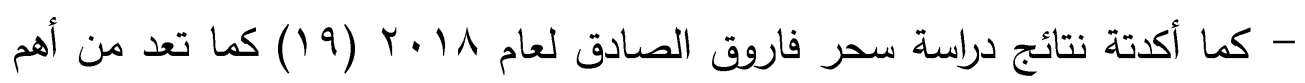

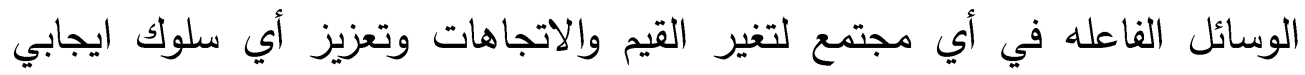

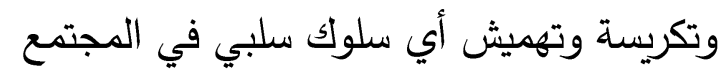

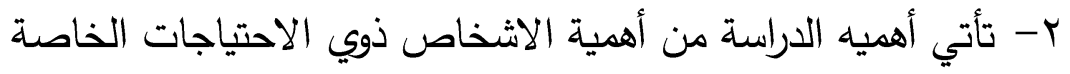

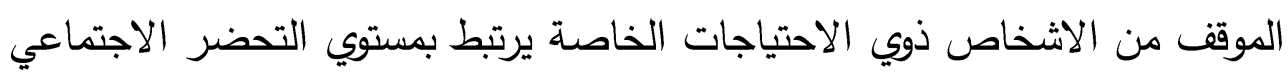

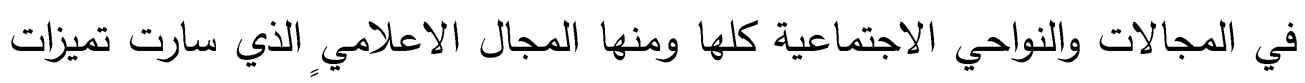

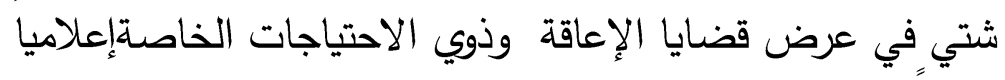

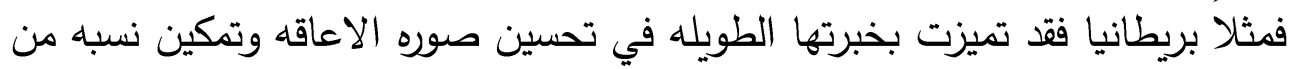

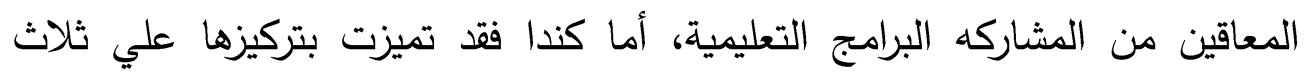

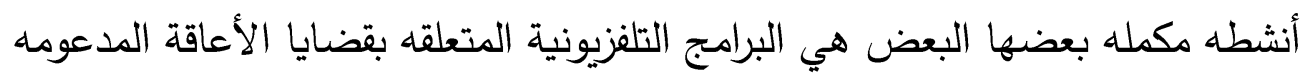
من قبل شبكه الاذاعه الرئيسيه والاحتفال بفيلم الإنه

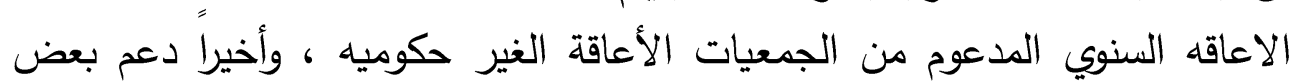

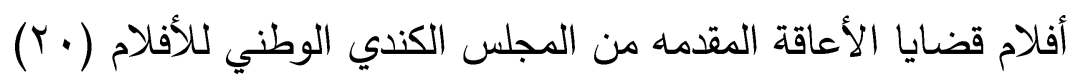

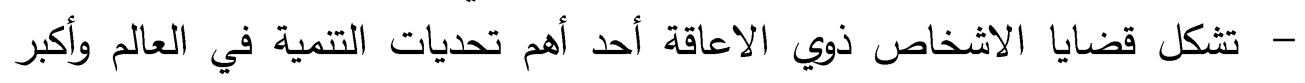

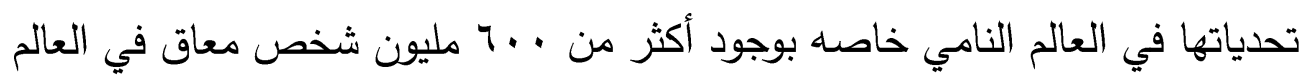


يعيش أكثر من •^ \% منهم في دول ناميه يعانون الفقر والمرض وتثير الأحصائيات

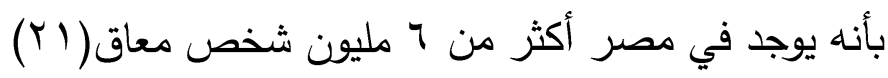

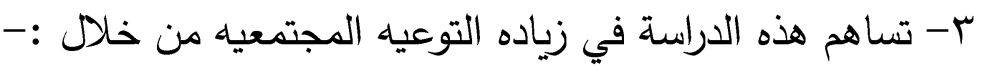

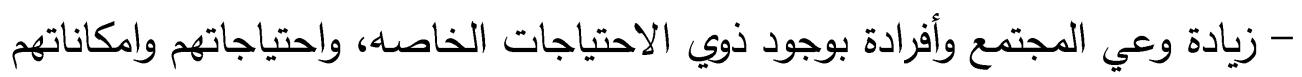
- التعريف بالاعاقة والاحتياجات الخاصه وأنواعها وأسابها، وكيفيه اكتثافها والوقائايه

منها

- تعزيز مكان ذوي الاحتياجات الخاصة في الدتمع والتعريف بحقوقهم واحتياجاتهم

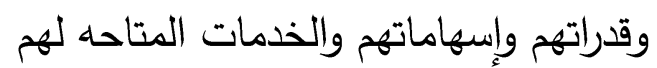

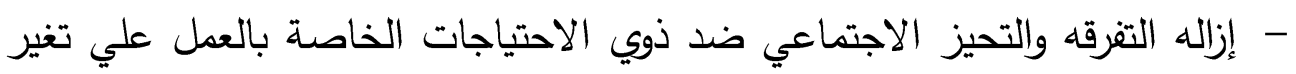

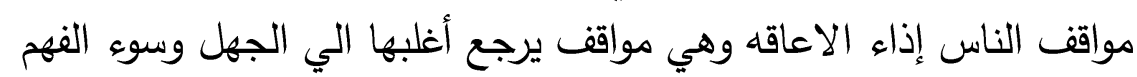
ع- تأتي أهميه الدراسة من أهميه البحوث الاعلاه الألامية الكفيله بتحديد الهتمامات

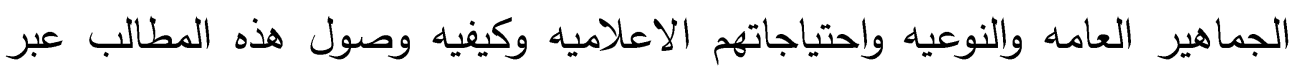

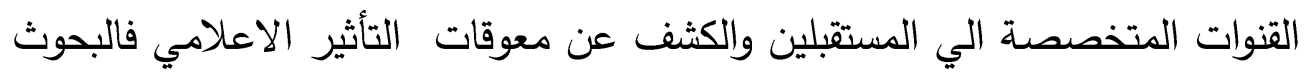

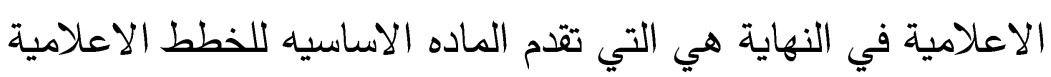
0- تساهم هذه الدراسة في توجيه أنظار الباحثين في مجال الاعلادي الإنام والقانون وعلم

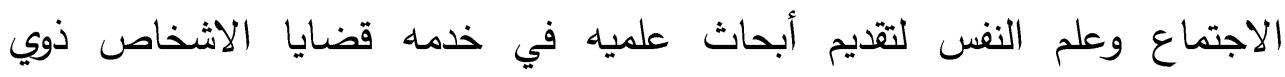
الاحتياجات الخاصة حتي يستفيد منها القائمين علي اعداد البادي البرامج الاذاعية والتلفزيون

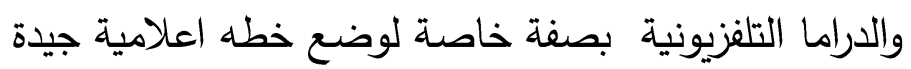

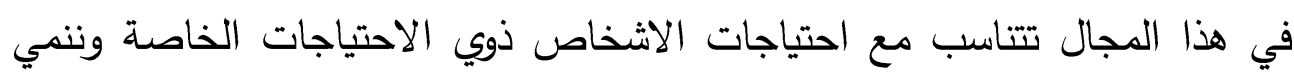

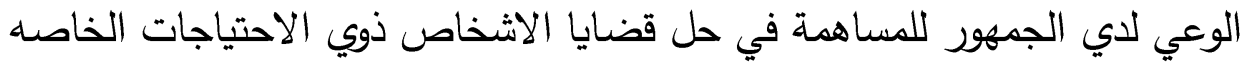

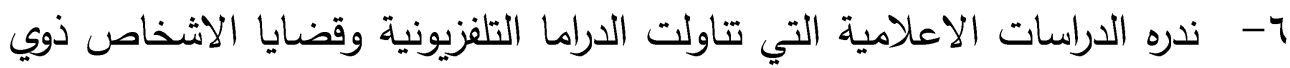

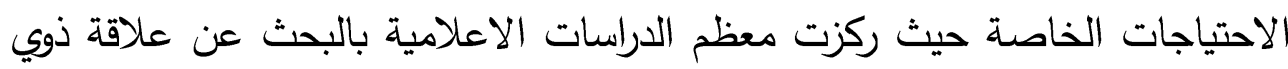

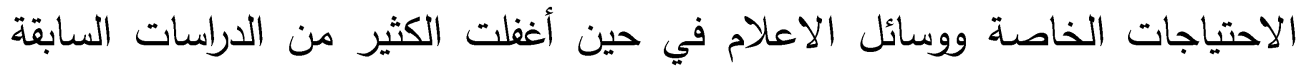

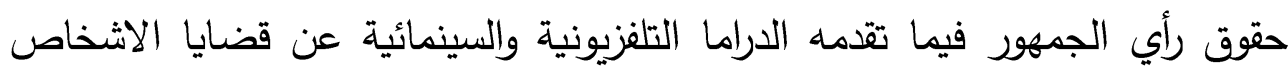
ذوي الاحتياجات الخاصة أهداف الدراسة :-

1- التعرف علي أكثر الوسائل الاعلاميه التي اهتمت بقضايا الاشخاص من ذوي الاحتياجات الخاصة r- التعرف علي أكثر الاشكال البرامجية التلفزيونية التي تناولت قضايا الاشخاص الاص

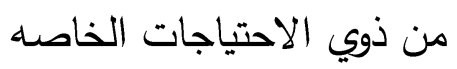


r- التعرف علي أبرز الافلام التليفزيونية السينمائية المصرية التي عرضت قضايا الاشخاص من ذوي الاحتياجات الخاصة كما تقدمها

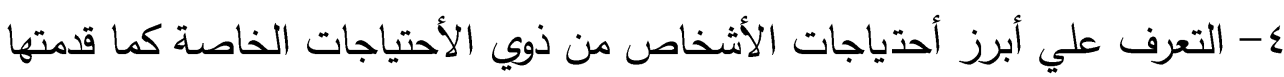

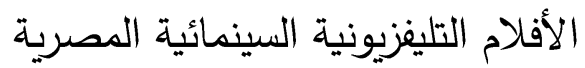

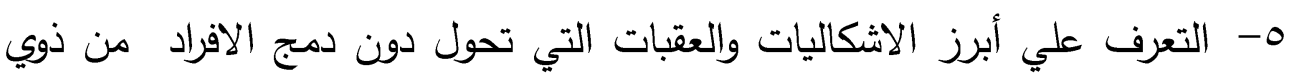

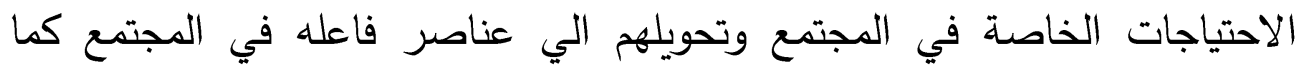
تقدمها الافلام التلفزيونية المصرية ז- التعرف علي صورة المعاقين ( ذوي الأحتياجات الخاصة ) كما تقدمها الأفلام التليفززيونية السينمائية المصرية V - التعرف علي الأنواع المختلفة من الأعاقة من ذوي الأحتياجات الخاصة التي التياتي قدمتها الأفلام التليفزيونية السينمائية المصرية الانية التئية ^- التعرف علي من تخاطب الافلام التلفزيونية السينمائية المصرية من المعنين

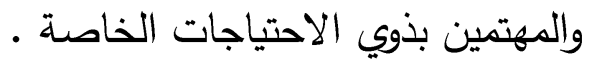

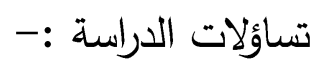

يتحدد التساؤل الرئيسي لهذه الدراسة في

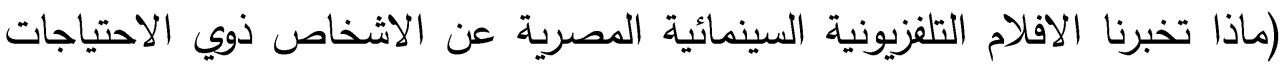

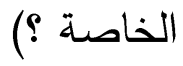
وينبثق من التساؤل الرئيسي عده تساؤلات فرعيه اخري يمكن بلورتها علي النحو

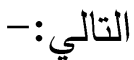
1- ما هي أكثر الوسائل الاعلاهية التي اهتمت بقضايا الاشخاص ذوي الاعاقات

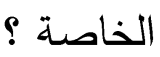
r- ما هي أكثر الاشكال البرامجيه التلفزيونية التي تتاولت قضايا الاشخاص ذوي

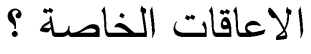
r- ما أبرز الافلام التليفزيونية السينمائية التي عرضت قضايا الاشخاص ذوي

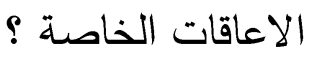
ع- ما ابرز احتياجات الاشخاص من ذوي الاحتياجات الخاصة التي قدمتها الافلام

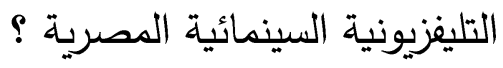


0- - ما هي ابرز الاشكاليات والعقبات التي حالت دون دمج الافراد من ذوي

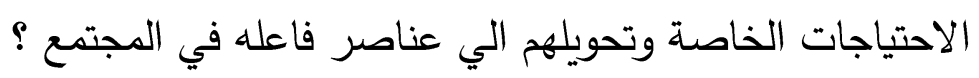
4- ما هي صوره الاشخاص ذوي الاحتياجات الخاصة كما قدمتها الافلام التلفزيونيه

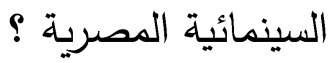
V- ما الانواع المختلفة من الاعاقة لذوي الاحتياجات الخاصة كما قدمتها الافلام التلفزيونية السينمائية ؟ 1- من الاشخاص التي تخاطبها الافلام التلفزيونية والسينمائية من المعنين والمهتمين بالاعاقه وذوي الاحتياجات الخاصة ؟ الاصن منهج الدراسة :-

تتتمي هذه الدراسة الي الدراسات الوصفية التي تسعي لوصف رؤيه المجتمع بجميع

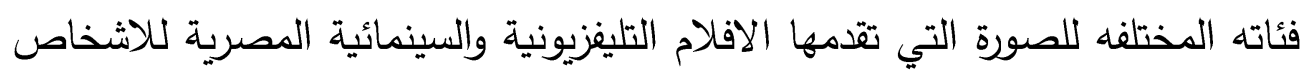

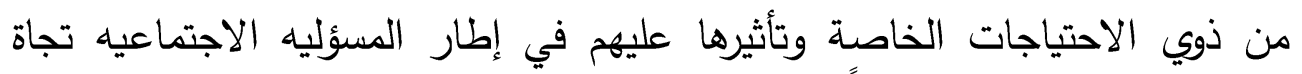

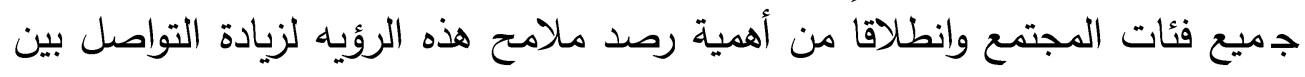

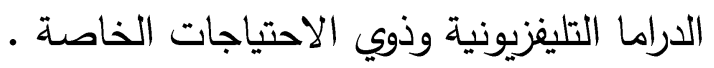

\section{عينه البحث :-}

تم تطبيق البحث علي عينة عمدية من أفراد المجتمع المصري تضم كل فئاتة العمرية

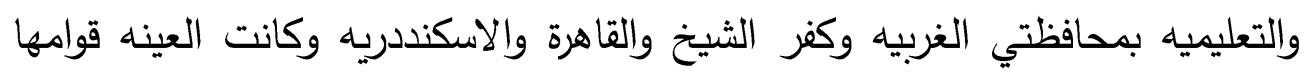

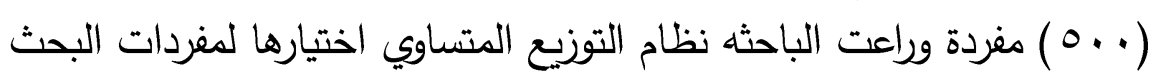

$$
\text { توصيف عينة الدراسة :- }
$$

فيما يلي توزيع عينة الدراسة وفقا للموقع الجغرافي : لئح

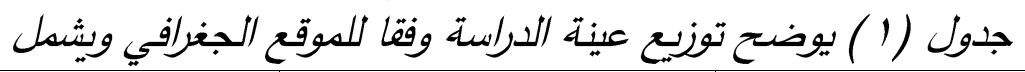

\begin{tabular}{|c|c|c|}
\hline النسبه المئوية & التكرار & الموقع الجغر افي \\
\hline$\%$ ro & Iro & محافظه الغربيةً \\
\hline$\%$ ro & Iro & محافظه كفر الثيخ \\
\hline$\%$ ro & Iro & محافظه القاهرة \\
\hline$\%$ ro & Iro & محافظه الأسكندريه \\
\hline
\end{tabular}

جدول (T) يوضح توزيع عينة الدراسة وفقا للفئات العدرية ويشهل

\begin{tabular}{|c|c|c|c|}
\hline النسبه المئويه & التكر ار & & الفئات العمريه \\
\hline \%ro & 1 To & $\begin{array}{l}-(Y) \\
(r)\end{array}$ & مرحلة المر اهقة من \\
\hline \%ro & 1 ro & & مرحلة الثباب من سن ) \\
\hline
\end{tabular}


11

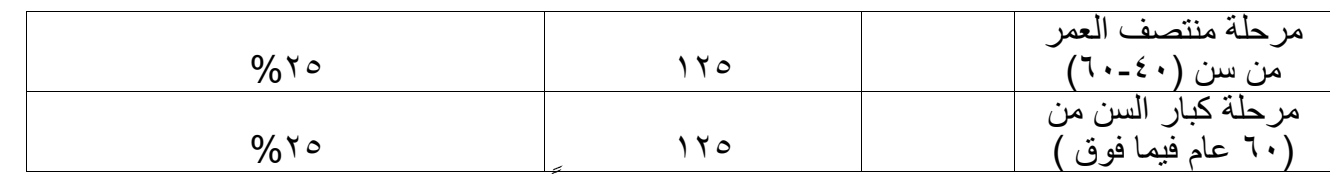

جذول (T) يوضح توزبيع عينة الدراسات وفقا للمراحل التعليميه المختلفة

\begin{tabular}{|c|c|c|}
\hline النسبه المئوية & التكر ار & الفئات العمريه \\
\hline$\%$ ro & Iro & أمى لا يقر اء و لا يكتب \\
\hline$\%$ ro & Iro & حاصل علي الثنهاده المتوسطه او \\
\hline$\%$ ro & Iro & حاصل علي درجه البكالريوس او \\
\hline$\%$ ro & ro & حاصل علي درجه الماجستير او \\
\hline
\end{tabular}

اعتمدت الدراسة علي أداه الاستبيان وتم وضع مجموعه من الاسئله طبقا لأهداف

الدراسة

صدق وثبات الأداة :-

عرضت الباحثه استمارة الاستبيان علي مجموعه من المحكمين للحكم علي مدي صلاحيتها كأداه مستخدمة للتحقق من أهداف الدراسة الميدانيه، أما بالنسبه لثبات الثئه

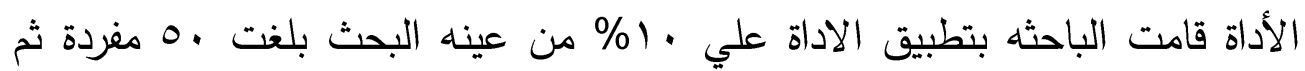
اعيد التطبيق مره أخري بعد فترة زمنيه أسبوعين بلغت من حساب الثبات الأول وجاءت نسبة تحليل الباحثه مع نفسها 97\% وهذا يدل علي صلاحيه المقياس

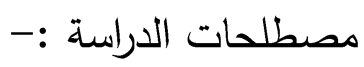
الافلام التليفزيونية السينمائية :- التهاهية يعرف الفيلم السينمائي بأنه عباره عن سلسله من الصور المتواليه الثابته عن موضوع، أو مشكلة، أو ظاهرة قضيه مطبوعه علي شريط ملفوف علي بكرة ويتم عرضها من خلال التليفزيون تتراوح مده عرضه من عشر دقائق إلي ساعتين حسب موضوعه

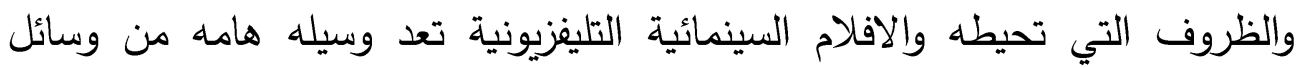
الاتصال التي يمكن استخدامها لتوضيح وتفسير التفاعلات والعلاقات المتغيرة في هي هني

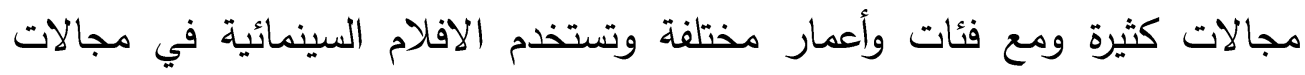
عديدة لاغراض متعددة حيث تستخدم في المجالات التعليميه والارشادية والزراعية والصناعية وتتراوح أغراضها بين الاعلام والارشاد والتثقيف وغير ذلك من الأغراض

الاخري كا الترفيه مثلا (Y)

الاعاقة تعني :- تعرف منظمه الصحة العالمية الاعاقة بأنها هي العجز والقيود علي

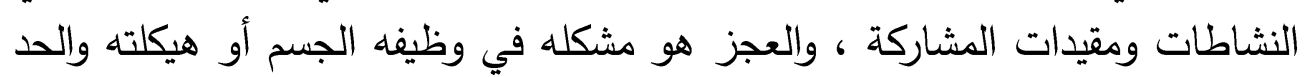


من النشاط هو الصعوبه التي يواجهها الفرد في تنفيذ مهمه أوعمل ، في حين ان تقيد

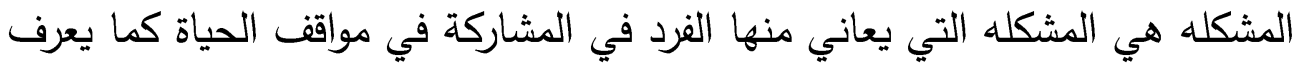
ذوي الاعاقة : بأنه الثخص الذي يختلف عن المستوي الثائع في المجتمع في صفته وقدرته الثخصية سواء كانت ظاهرة التخلف العقلي والصمم والاعاقات السلوكية والعاطفية حيث يستوجب ذلك تعديلا مع المتطلبات التعلميه والتربوية والحياتية بشكل

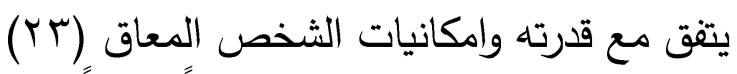

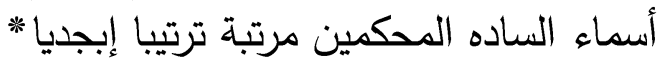

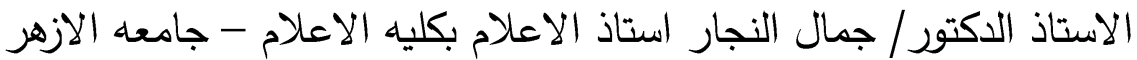

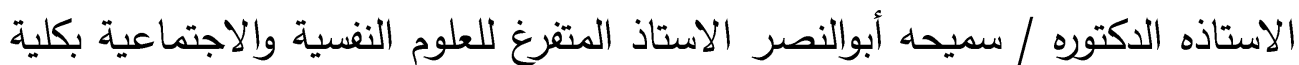

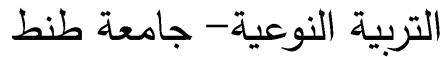

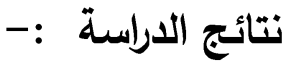

تستعرض الباحثة أهم النتائج التي توصلت اليها من خلال الدراسة الميدانية علي

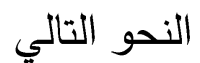
1- أكثر الوسائل الاعلامية التي اهتمت بقضايا الاشخاص من ذوي الاحتياجات

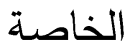
جدول (乏) يوضح أراء أفراد العينة حول أكثر الوسائل الاعلامية التي اهتمت بقضايا

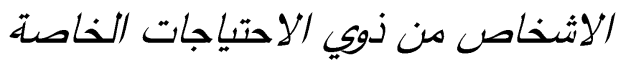

\begin{tabular}{|c|c|c|c|}
\hline الترتيب & النسبة المئوية & التكر ار & 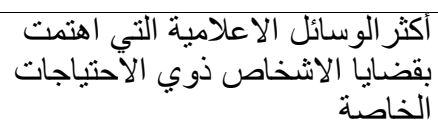 \\
\hline 1 & $\%$. & ro. & التليفزيون \\
\hline$\varepsilon$ & $\%$ !. & 0. & الر اديو \\
\hline r & $\% r$. & $1 \ldots$ & الصحف \\
\hline$r$ & $\% r$. & $1 \ldots$ & الانترنت \\
\hline & $\% 1 .$. & $0 .$. & الدجموع \\
\hline
\end{tabular}

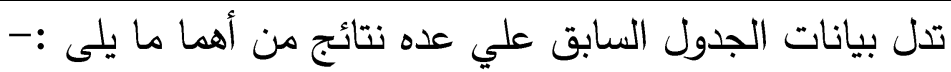

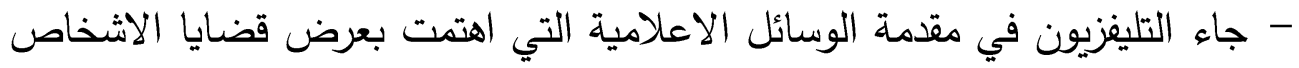

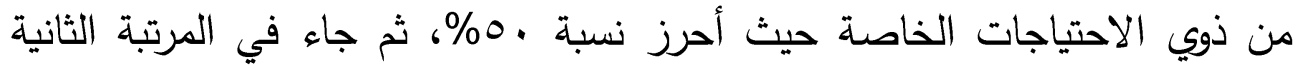

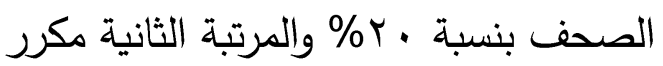

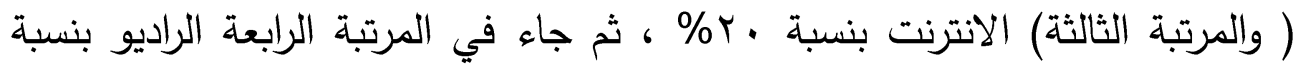
$\% 1$.

- وترجع الباحثة تقدم التليفزيون علي باقي وسائل الاعلام في الاهتمام بعرض قضايا

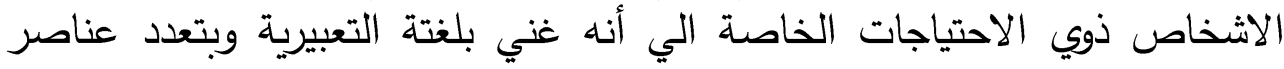
التجسيد، الغني في مادته وبتعدد الحواس التي يخاطبها لتيها فيستخدم التليفزيون الكلمه 


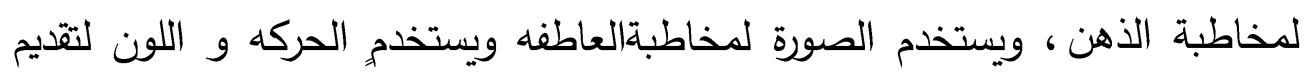

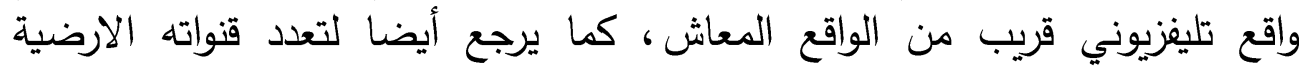

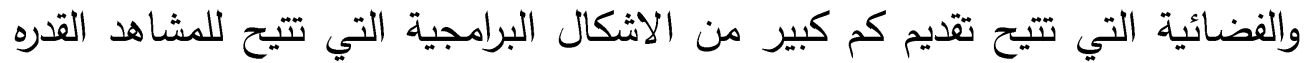

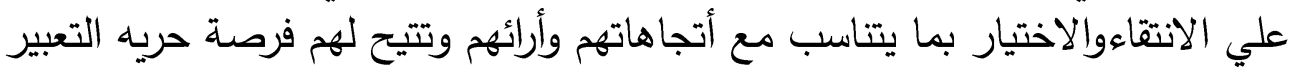

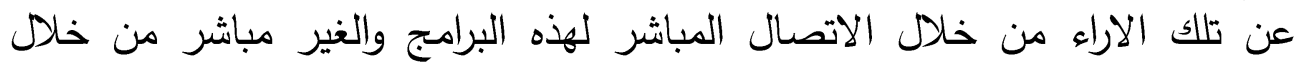

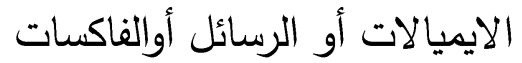
r- أكثر الاثكال البرامجيه التليفزيونية التي تلناولت قضايا الآثخاص من ذوي

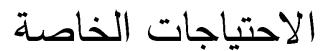
جدول (0) يوضح أراء أفراد العينه حول أكثر الاشكال البرامجية التليفزيونية التي التيات

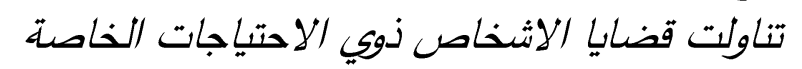

\begin{tabular}{|c|c|c|c|}
\hline الترتيب & النسبة المئوية & التكر ار & 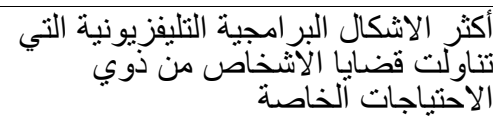 \\
\hline 1 & $\%^{7}$. & $\mu \cdots$ & الافلوا التليفزيونية السينمائية \\
\hline r & $\% r r$ & 11. & المسلسلات ت الم \\
\hline 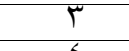 & $\% v$ & ro & I \\
\hline$:$ & $\% 7$ & ri. & آلا \\
\hline & $\% 1 .$. & $0 \ldots$ & \\
\hline
\end{tabular}

تدل بيانات الجدول السابق علي عده نتائج من أهمها ما يلي :-

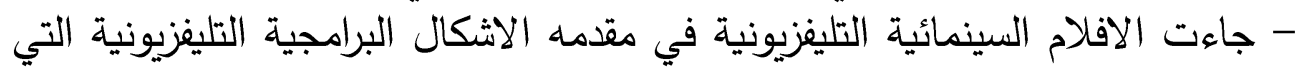

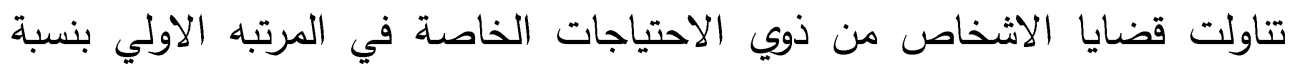

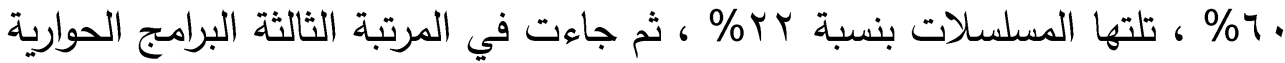

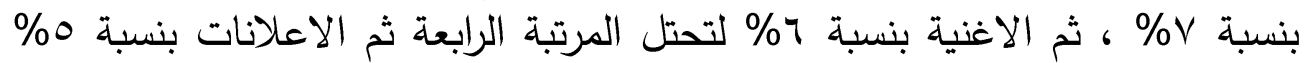

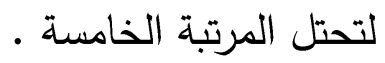

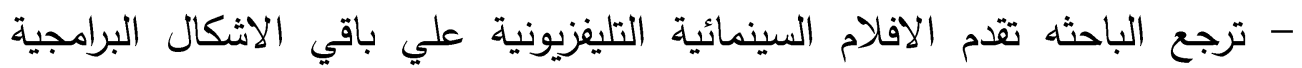

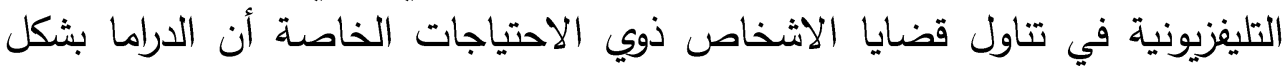

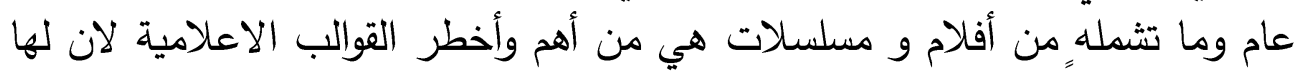

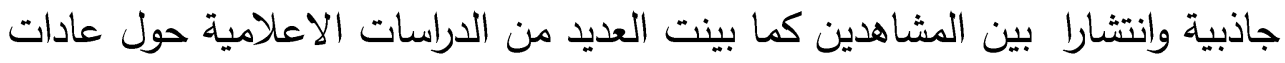

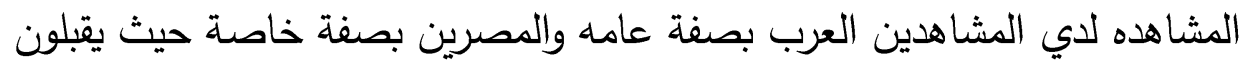

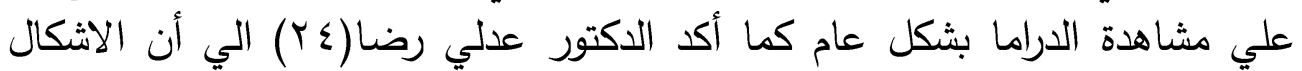

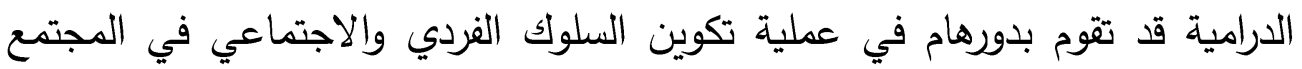

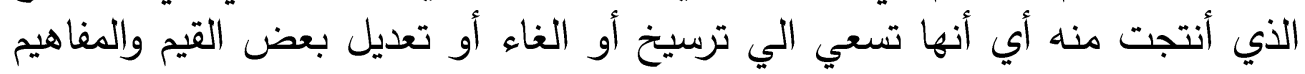

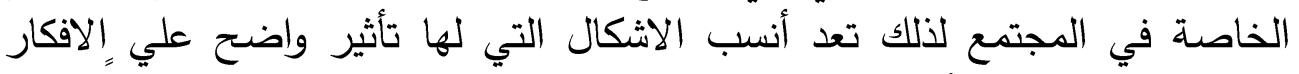
وال لاتجاهات بتدعيمها أو تبديلها وسلوك الجماهير اذا ما تم استخدامها استخداما رشيد التيد 
r- أبرز الافلام التليفزيونية السينمائية التي عرضت قضايا الاشخاص ذوي الاحتياجات الخاصة جلول (7) يوضح أراء أفراد العينتة حول /بزالافلام التليفزيونية السينمائية التي التي

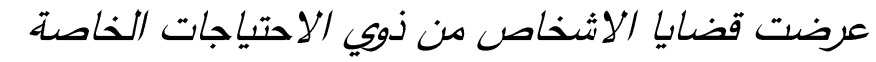

\begin{tabular}{|c|c|c|c|}
\hline الترتيب & النسبة المئوية & ( التكرار ) & 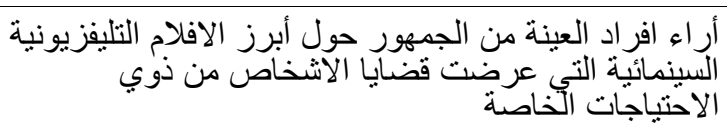 \\
\hline$\varepsilon$ & \%ाr. & YIV & الثنمو ع السو داء \\
\hline 0 & $\% \circ . \dot{v}$ & 90 & قتديل أم هاشّ \\
\hline 1 & \%Yr.Y & $r 70$ & الكيت كات \\
\hline 9 & $\% r$ & Tr & الصَرخة \\
\hline$r$ & $\% 10$ & $r \leqslant 0$ & امير الظلام \\
\hline Y & $\% r$. & TTV & طه حسين \\
\hline 7 & $\% 0.1$ & $\Lambda \varepsilon$ & ايوب \\
\hline$\Lambda$ & $\%$ & $\varepsilon V$ & الخرساء \\
\hline$\varepsilon$ & $\% v$ & 110 & ئ تَلبي \\
\hline 1. & $\% 9$ & 10 & ري آلّوحوش \\
\hline 9 & $\%{ }^{1} . \mathrm{r}$ & Y. & حر| \\
\hline $\mathrm{v}$ & $\%{ }^{\circ}$ & A. & توت توت \\
\hline & $\% 1 \ldots$ & $17 \varepsilon \Gamma$ & المجموع \\
\hline
\end{tabular}

تذل بيانات الجدول السابق علي عده نتائج من أهمها :-- جاء فيلم الكيت كات في مقدمه الافلام التليفزيونية السينمائية التي عرضت فئ قضايا

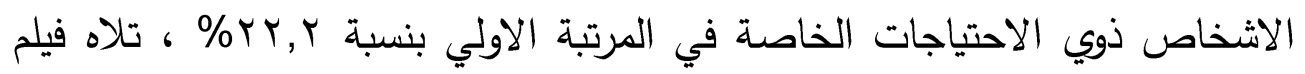

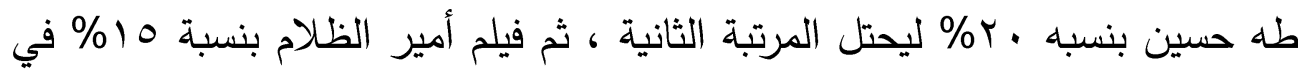
المرتبة الثالثة ، ثم جاء في المرتبة الرابعه فيلم رد قلبي V \% ثم فيلم قنديل أم هاشم

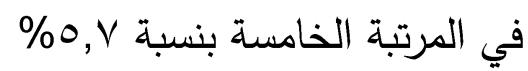
- ترجع الباحثه تقدم فيلم الكيت كات وطه حسين وأمير الظلام في المراتب الاولي

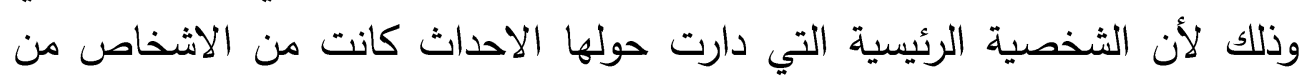
ذوي الاحتياجات الخاصة ولم يكن تلك الشخصيات من الشخصيات الثانوية المساعدة

للشخصيات الرئيسية ع - أبرز احتياجات الاشخاص من ذوي الاحتياجات الخاصة والتي قد بينتها الافلام

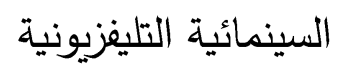

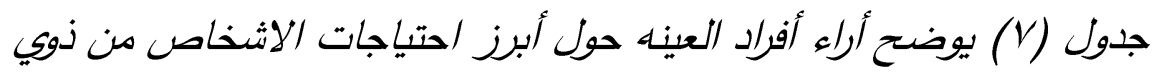
الاحتياجات الخاصة والتي قدمتها الافلام السينمائية التلينزيونية

\begin{tabular}{|c|c|c|c|}
\hline الترنيب & النسبة المئوية & التكر ار & 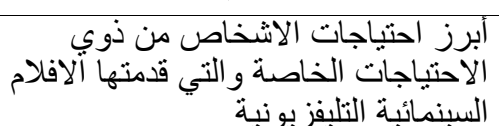 \\
\hline 1 & $\% \circ 9$ & r9o & احتياجات اجتماعية \\
\hline
\end{tabular}




\begin{tabular}{|c|c|c|c|}
\hline r & \% & 100 & احتياجات صحية \\
\hline$r$ & $\% 1$. & 0. & احتياجات تعليمية \\
\hline & $\% 1 \ldots$ & $0 \ldots$ & المجموع \\
\hline
\end{tabular}

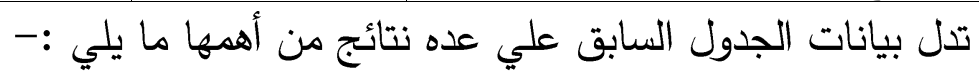

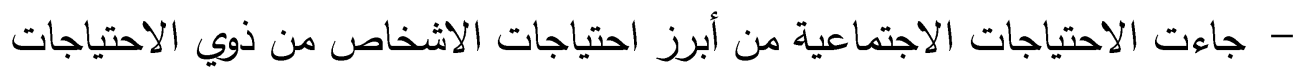

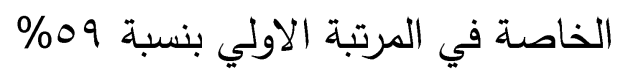

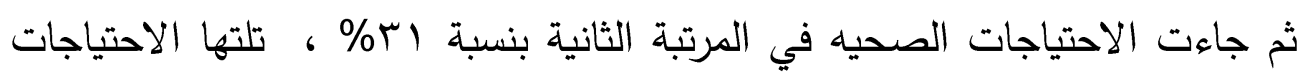
التعليميه بنسبة ، ( \% لتحتل المرتبة الثالثة

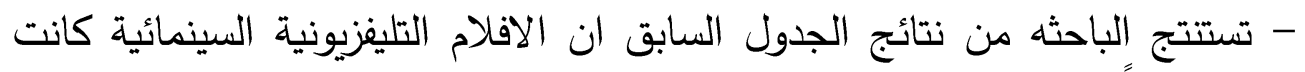
اكثر تركيزا علي الاحتياجات الاجتماعية للاشخاص من ذوي الاحتياجات الخاصة

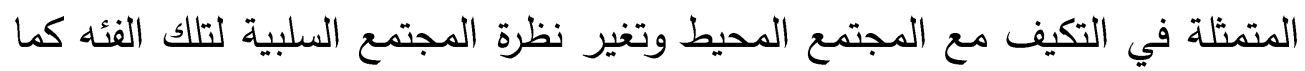
ظهر ذلك بوضوح في كثير من الأفلام مثل فيلم الكيت كات والشموع السوداء وتوت

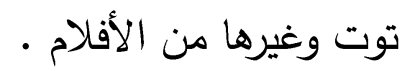
0- الاشكاليات والعقبات التي تحول دون دمج الافراد من ذوي الاحتياجات الخاصة

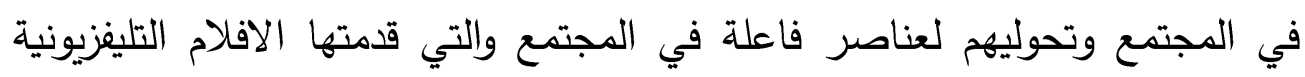
السينمائية. جدول (N) يوضح أراء أفراد العينة حول الاشكاليات والعقبات التي تحول دون دمج

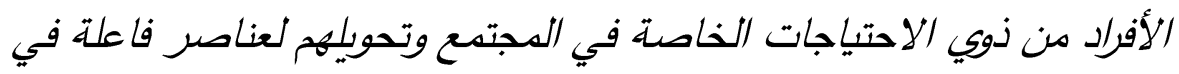
المجتهع والتهي قدمتها الافلام التليفزيونية السينمائية

\begin{tabular}{|c|c|c|c|}
\hline الترنيب & 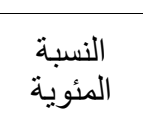 & التكر ار & 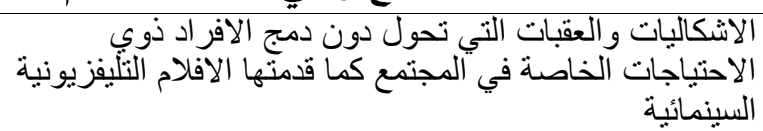 \\
\hline$r$ & $\% 10,0$ & 198 & التحديات السلوكية لذوي الاحتياجات الخاصة \\
\hline$\varepsilon$ & $\%) \leq, r$ & IVA & صعوبة في دمجهم في سوق العمل \\
\hline r & $\% 17,0$ & Y). & الصحة العقلية \\
\hline 0 & $\% \backslash r, r$ & 100 & الدعم المادي \\
\hline 1 & $\%$ \%r, & rqV & نظره المجتمع الدونية للافر اد من ذوي الاحتياجات الخاصة \\
\hline V & $\% \varepsilon, \varepsilon$ & OV & التأهيل النفسي للمعاقين للامج داخل المجتمع \\
\hline 7 & $\% 1 \cdot, r$ & r. & مشكلات التعليم و التعلم \\
\hline \multirow[t]{2}{*}{$\wedge$} & $\% r, r$ & 45 & تأهيل الافر اد القائمين علي تعليم الاشخاص المعاقين لمساعدتهم \\
\hline & $\% 1 \ldots$ & 1479 & 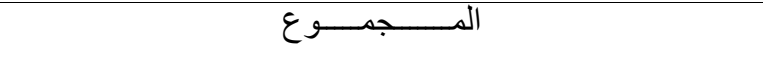 \\
\hline
\end{tabular}

تدل بيانات الجدول السابق علي عده نتائج مايلي :- 
جاءت نظره المجتمع الدونيه للاشخاص من ذوي الاحتياجات الخاصة في المرتبة

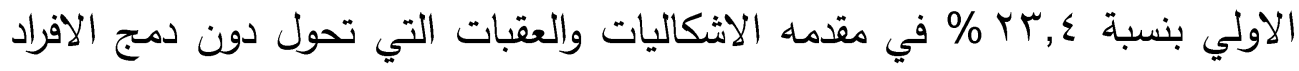

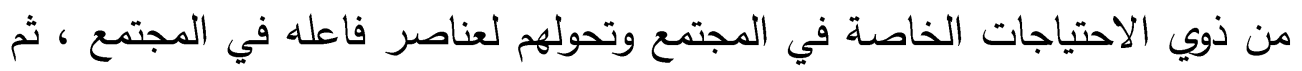

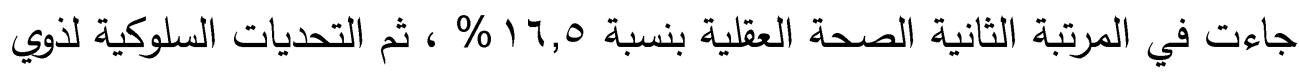

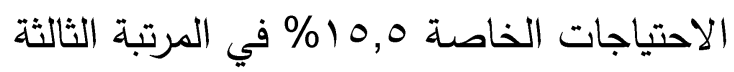

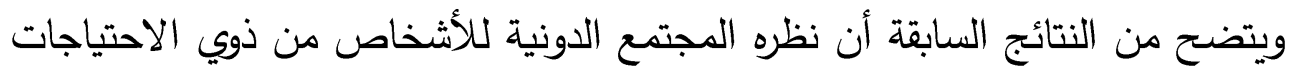

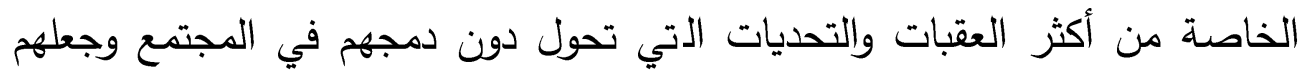

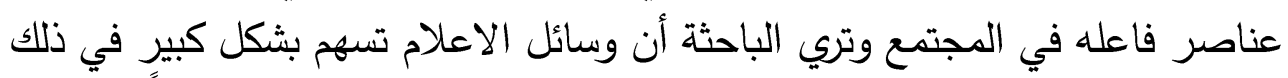

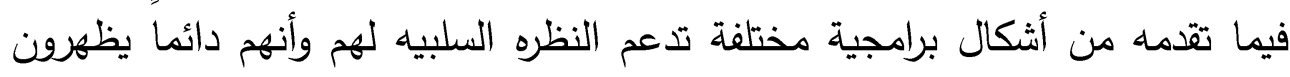
وبخاصة في الافلام والمسلسلات / تمثليات / مسرحيات في أغلبها تغذئي أذهان

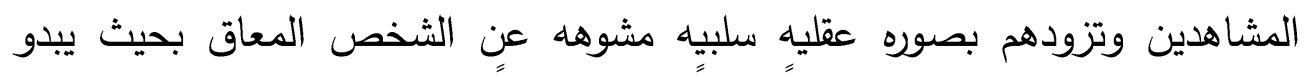

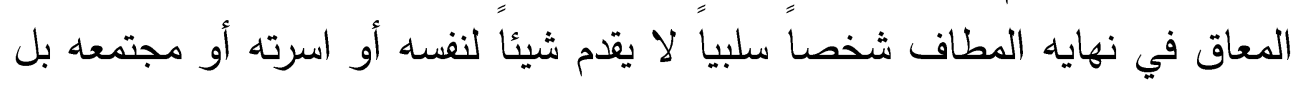

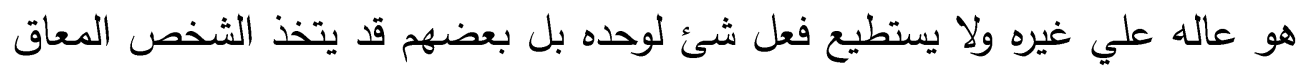

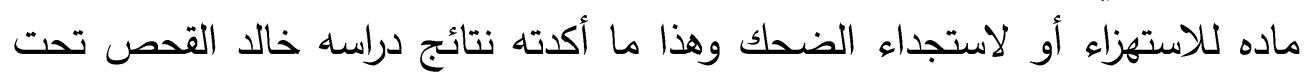

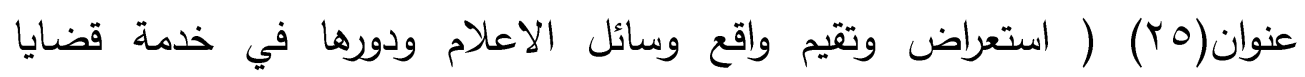

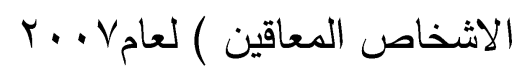

7- صوره الاشخاص ذوي الاحتياجات الخاصه كما قدمتها الافلام التليفزيونيه السينمائية

جلول (9) يوضح أراء أفراد العينه حول صوره الأشخاص من ذوي الاحتياجات

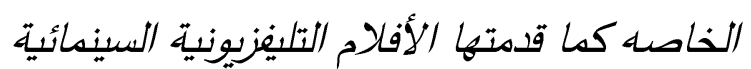

\begin{tabular}{|c|c|c|c|}
\hline الترتيب & النسبة العئوية & 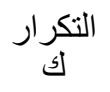 & 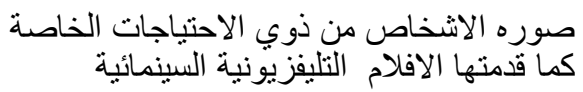 \\
\hline 1 & $\% \varepsilon . r$ & 70 & اشخاص خطرون و اشر ار \\
\hline 0 & $\% \circ$ & vo & اشخاص عدائيون غاضبون \\
\hline 1 & $\% \leqslant 0$ & TVo & اشخاص مثيرون للثفقه والعطف \\
\hline 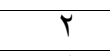 & $\%$ \% ${ }^{\top}$ & rTO & اشخاص عاجزون وغير مهرة \\
\hline$\varepsilon$ & $\%^{v} .^{r}$ & 11. & اشخاص مهرجون ومضحكون \\
\hline $\mathrm{v}$ & $\% r$ & $r$. & اشخاص سيأون حتي علي نفسهم \\
\hline$\hat{\lambda}_{\mu}$ & $\% \cdot .7$ & ì. & اثخاص معجزون خارقون . \\
\hline r & $\% 1\{$ & r. & الشخاص عاله علي الاخرون \\
\hline & $\% 1 .$. & $10 \%$ & المجموع \\
\hline
\end{tabular}

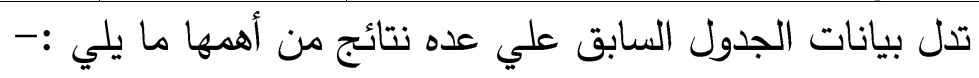

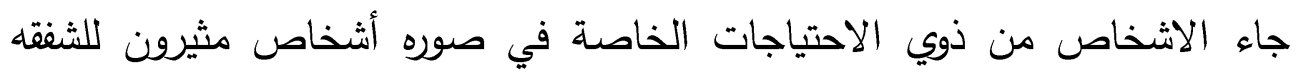

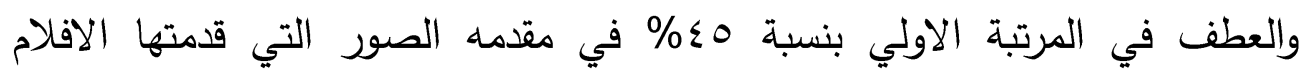


التليفزيونية السينمائية للاشخاص ذوي الاحتياجات الخاصة ثم جاء في المرتبة الثانية

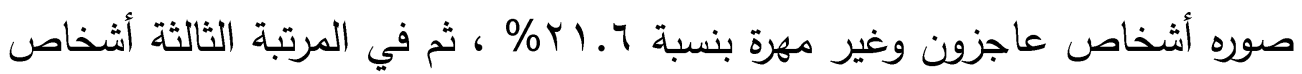

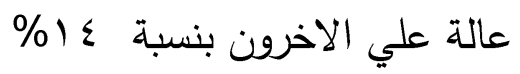

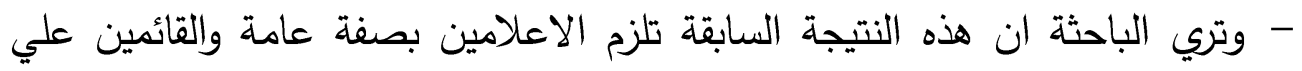

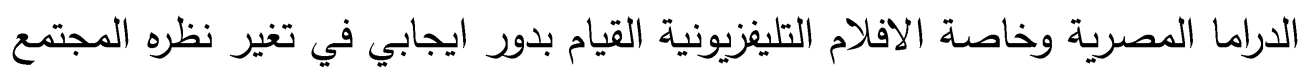

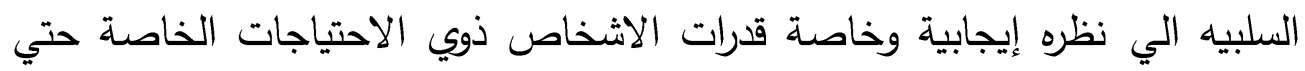

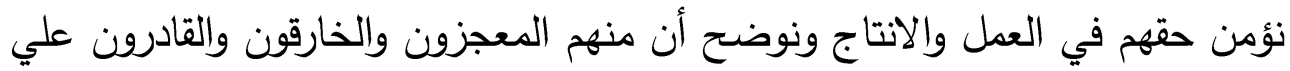

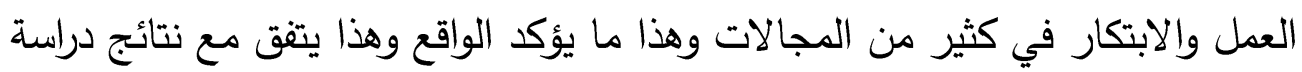

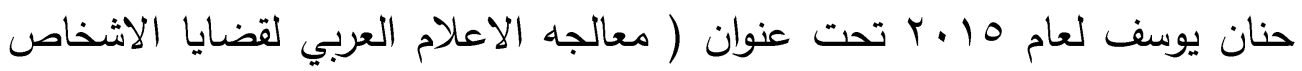

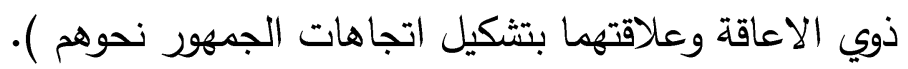
V- الانواع المختلفة للاعاقة التي قدمتها الافلام التليفزيونية السينمائية .

جدول (• (1) يوضح أراء أفراد العينه حول الانواع الدختلفة للاعاقة التي قدمتها الافلام التليفزيونية السيندائية

\begin{tabular}{|c|c|c|c|}
\hline الترتيب & النسبة الصئوية & التكر ار & 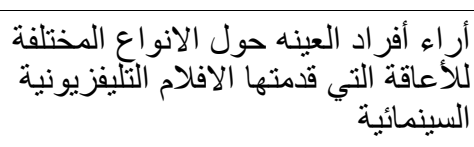 \\
\hline r & $\% r 1.0$ & Trt & فقد البصر \\
\hline$r$ & $\% 10.1$ & YYY & فق الذاكرة \\
\hline 1 & $\% \leqslant 0$ & TVO & الاضطر ابات العقلية و النفسية و الذهنية \\
\hline 7 & $\% \curlyvee . \uparrow$ & $\varepsilon$. & التشو هات الجسديه \\
\hline$\Lambda$ & $\% r$ & $r$. & فق فقد السمع \\
\hline 9 & $\% r$ & $r$ r. & اضطر ابات التعلم \\
\hline$\varepsilon$ & $\% \varepsilon . \varepsilon$ & TV & التوحد واضطر ابات السلوك \\
\hline v & $\% r . r$ & ro & العجز الوظيفي \\
\hline o & $\%$ ६ & 01 & قصر القامه \\
\hline 1. & $\%$ & 10 & اصابه العمود الفقر \\
\hline
\end{tabular}

تدل بيانات الجدول السابق علي عده نتائج من أهمها ما يلي :-

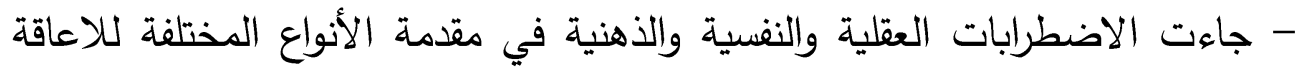

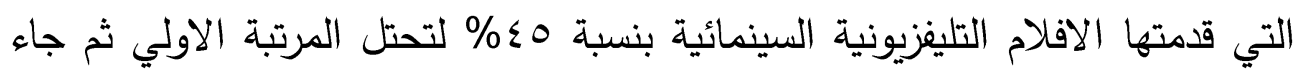

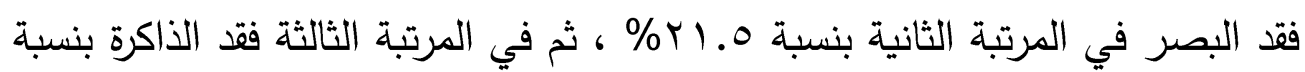
$\% 10.1$

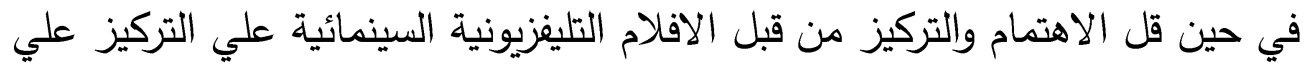

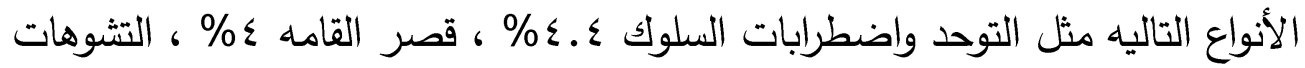




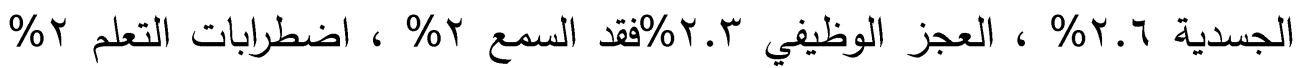

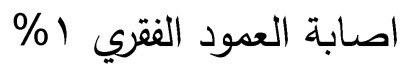
وتؤكد النتائج السابقة أن الافلام التليزيونية السينمائية في ذلك لم تستطع تسليط الضوء علي كافة أنواع الاعاقة التي يعاني منها الاشخاص من ذوي الاحتياجات الخاصة وقد ترجع الباحثة السبب الرئيسي في ذلك الي عدم وجود خبره لدي القائمين علي كتابة تلك الافِلام عن هذه الفئه فلابد أن يكونوا علي علم ومعرفة بأنواع اعاقتهم واحتياجاتهم وايضا المشاكل التي يواجهونها في المجتمع هنه 1- من هم الاشخاص الذين تخاطبهم الافلام التليفزيونية السينمائية من المعنين بالاعاقة وذوي الاحتياجات الخاصة

جلول (1) يوضح أراء أفراد العينة في هن هم الأثخاص الذين تخاطبهم الأفلام

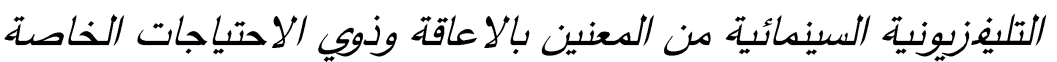

\begin{tabular}{|c|c|c|c|}
\hline الترتيب & 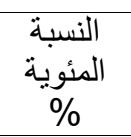 & التكرار & 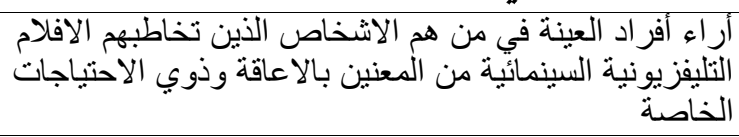 \\
\hline r & $\%$ \% & $\varepsilon \cdots$ & ذوي الاحتياجات الخاصة \\
\hline 1 & $\% \leqslant \varepsilon .7$ & $T V$. & تخاطب اسر هم \\
\hline r & $\% 17$ & r६. & المتخصصين في مجال ذوي الاحتياجات الخاصة من أطباء \\
\hline$\varepsilon$ & $\% 0^{0}$ & Vo & متخصصين في مجال ذوي الاحتياجات الخاصة من النفسيين \\
\hline 0 & $\% \varepsilon . \Gamma$ & 70 & وذوي الاحنين فجآل الخدمة الإجتماعية المتخصصين في الاعاقة \\
\hline \multirow[t]{2}{*}{7} & \% r. & ○. & الاعلامين من الصحفييين والاذاعين والتليفزيوني \\
\hline & $\% 1 \ldots$ & $10 \ldots$ & المجموع \\
\hline
\end{tabular}

تدل بيانات الجدول السابق علي عده نتائج من أهمها مايلي :- جاءت الاسر في مقدمة الاشخاص الذين تخاطبهم الافلام التليفزيونية السينمائية

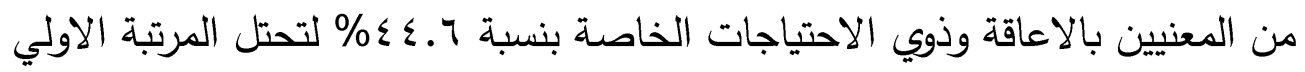

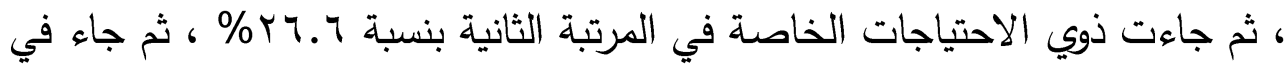
المرتبة الثالثة المتخصصين في مجال ذوي الاحتياجات الخاصة من أطباء بنسبة $\% 17$

- في حين قل مخاطبة الافلام التليفزيونية السينمائية لكل من المتخصصين في مجال ذوي الاحتياجات الخاصة من النفسيين 0\% ، والعاملين في مجال الخدمة الاجتماعية 
من المتخصصين في الاعاقة وذوي الاحتياجات الخاصة ب.ء٪\% ، الاعلاميين من

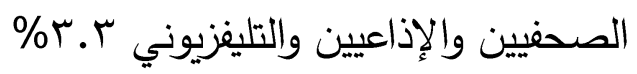

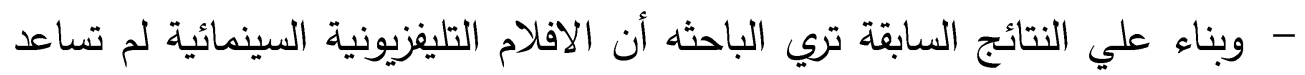

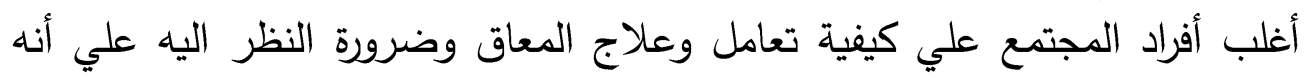

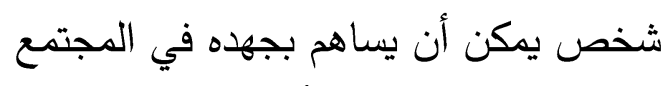

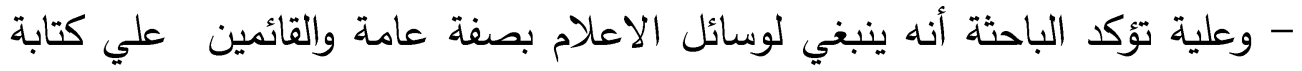

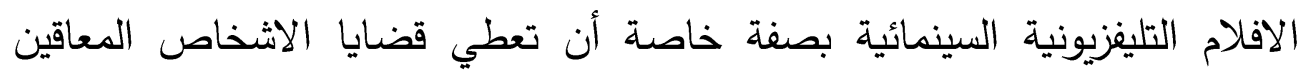

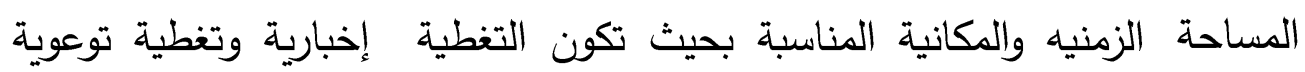

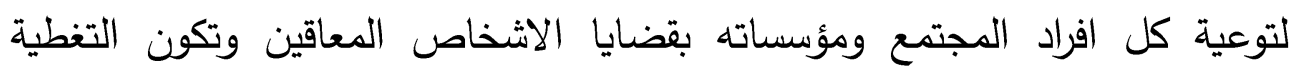

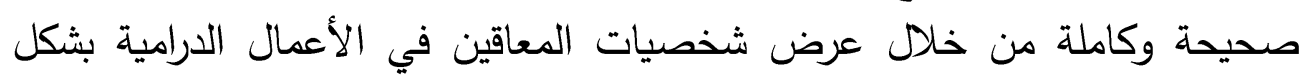
إيجابي وبناء وليس بشكل سلبي ومنفر من فرل عرون

ألرالـتائجة العامة للدراسية

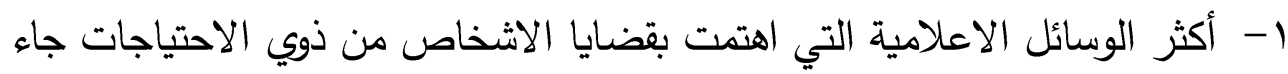

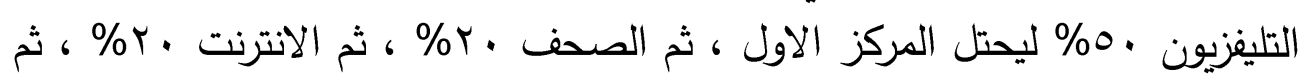

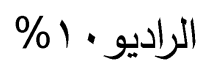

r- جاءت الافلام التليفزيونية السينمائية في مقدمة الأثكال البرامجية التليفزيونية

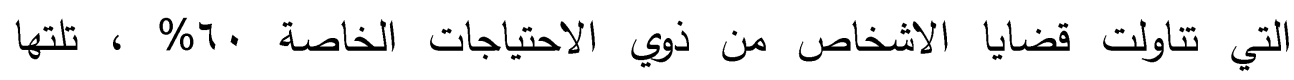

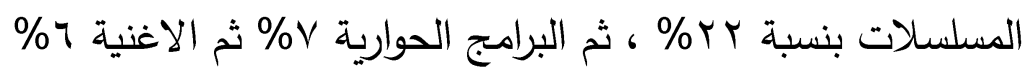

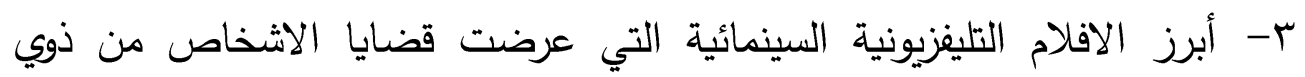

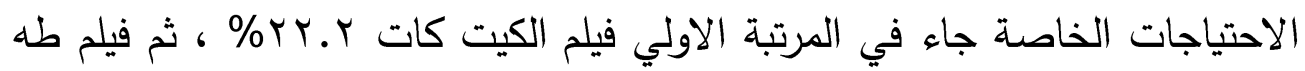

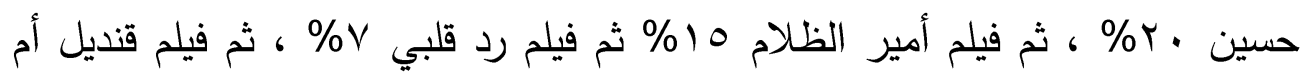
هo.V هاشم ع - جاءت نظره المجتمع الدونيه للاشخاص من ذوي الاحتياجات الخاصة في مقدمة

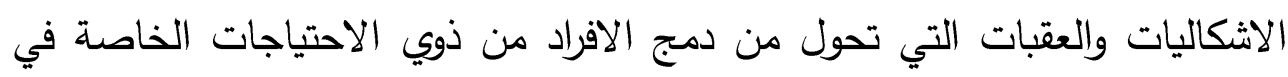

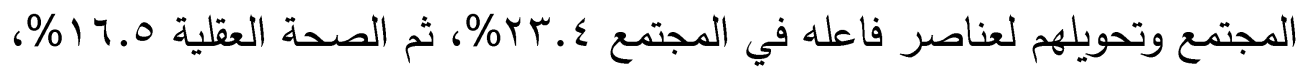

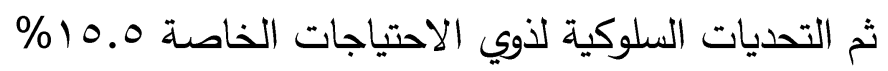

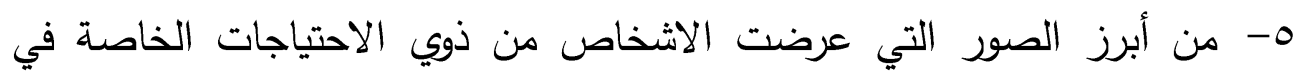

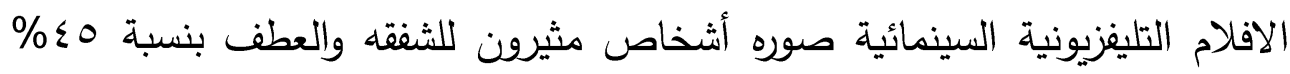




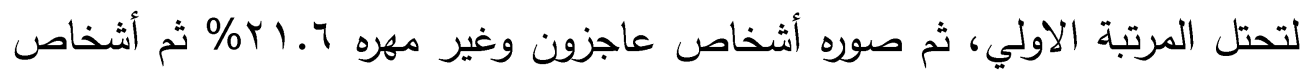

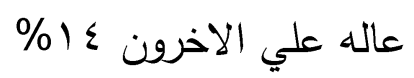

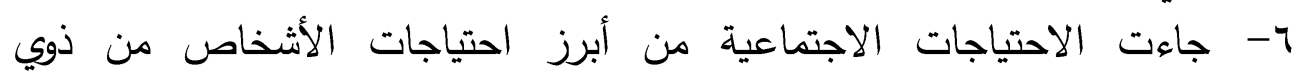

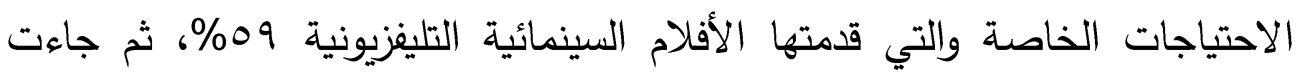

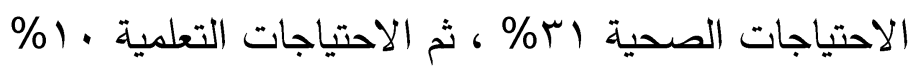

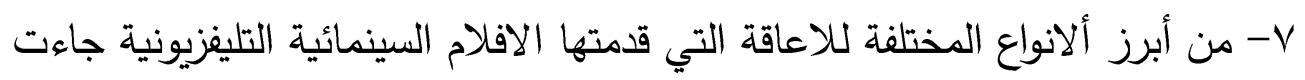

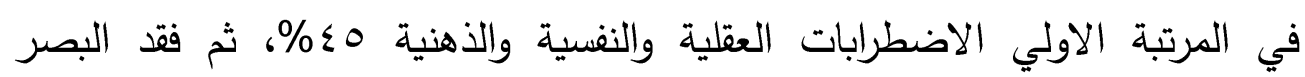

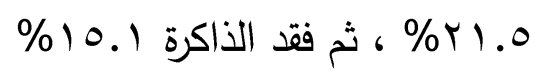
^- جاءت الأسر في مقدمة الاشخاص الذين تخاطبهم الافلام التليفزيونية السينمائية

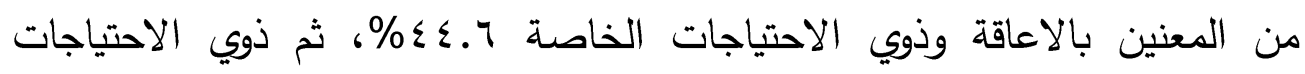

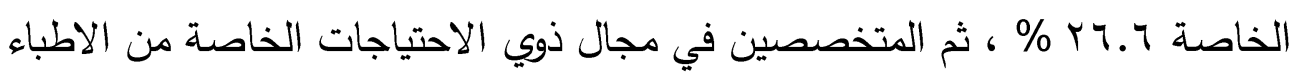

. \%17

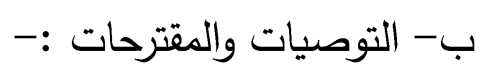

ا- ضرورة اهتمام جميع وسائل الأعلام المختلفة بقضايا الأشخاص من ذات ذوي

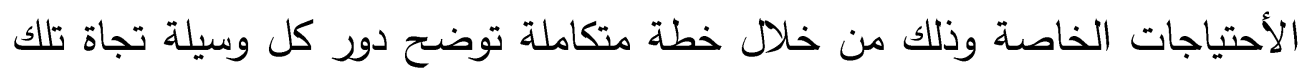

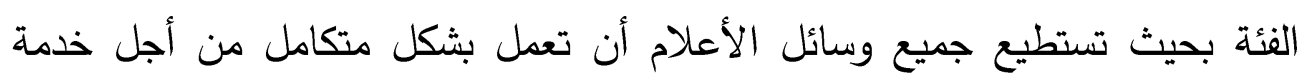

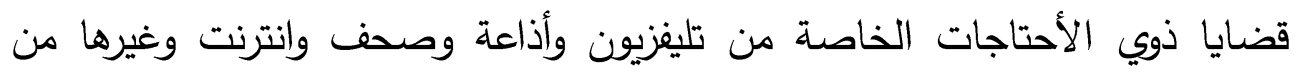

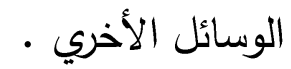

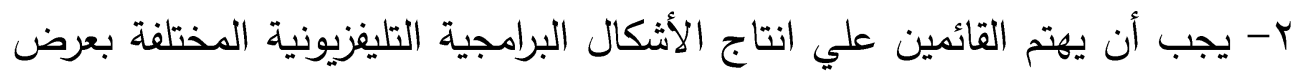

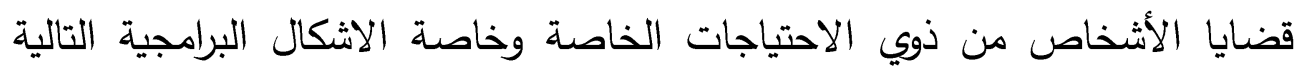

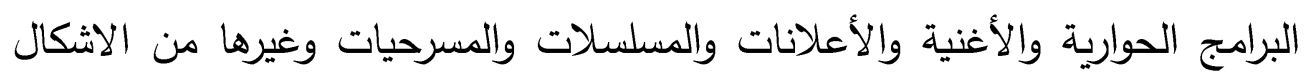
الدرامية الأخري r- انتاج المزيد من الأفلام التليفزيونية السينمائية لعرض القضايا الأجتماعية والطبية

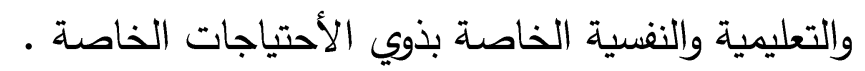
ع - يجب أن يهتم القائمين علي الأفلام التليفزيونية السينمائية بعرض الألثاتية الأثكاليات

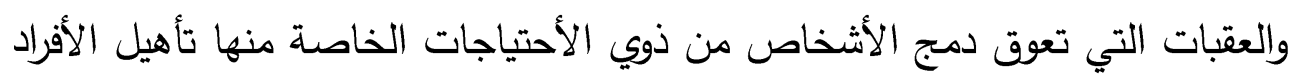

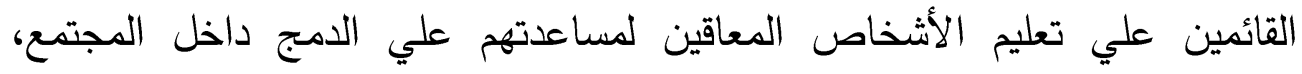

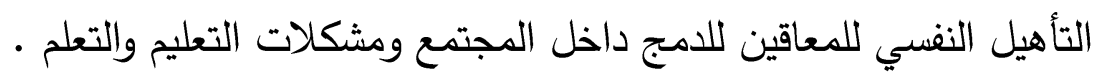

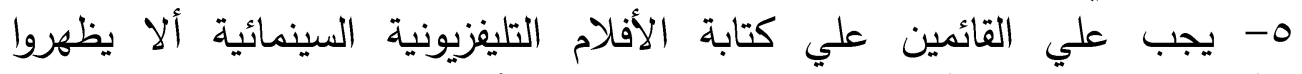

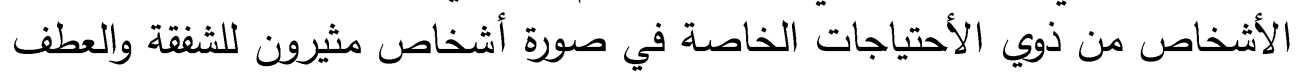


وعليهم أظهارهم في صورة أثخاص يمتلكون قدرات خاصة يمكن أن يستقيد منهم

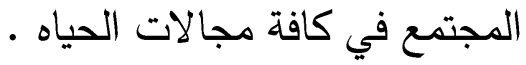

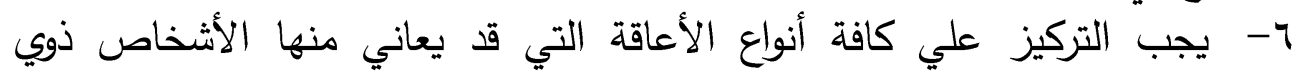

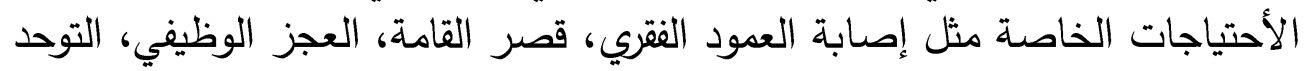

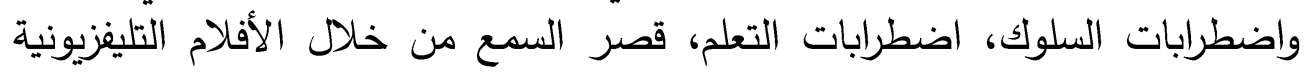

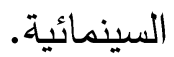

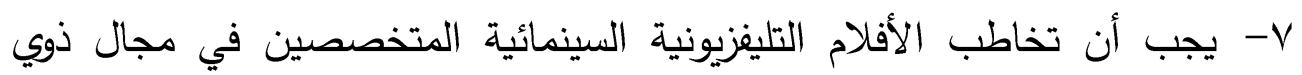

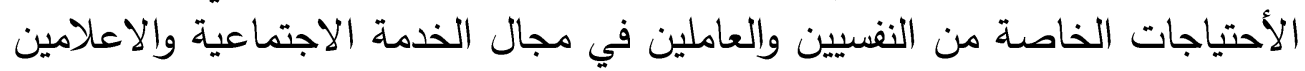

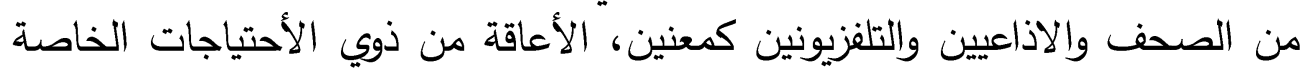

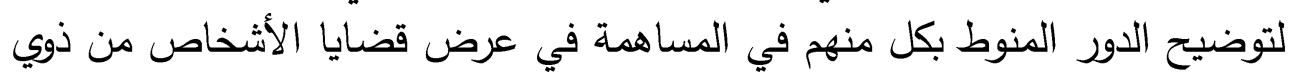

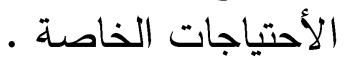

1- مراعاة الاشراف العلمي الدقيق علي مِاداد إلبرامج الأعلامية والدراما التليفزيوية

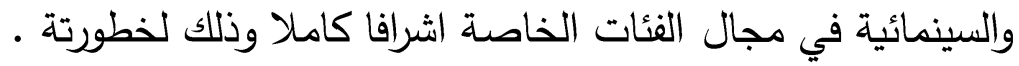

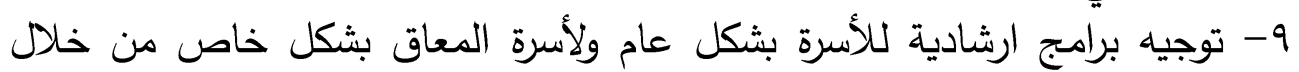

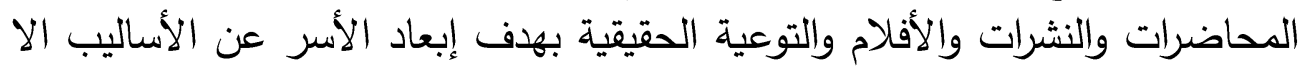

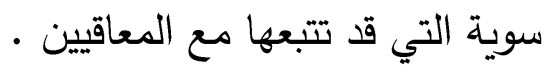

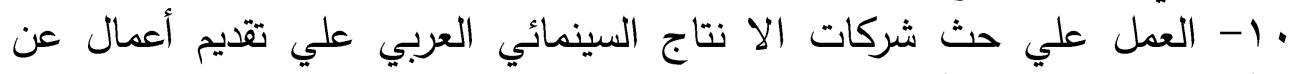

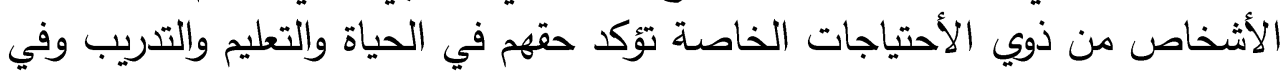

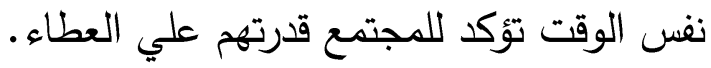

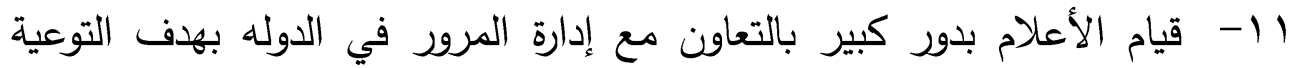

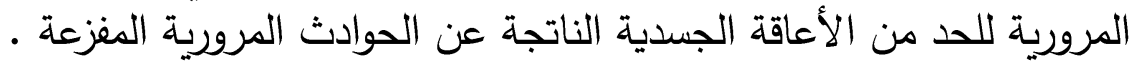

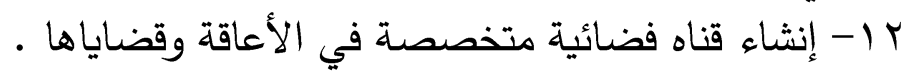

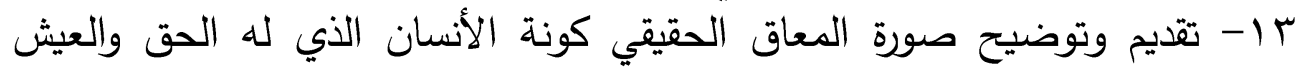

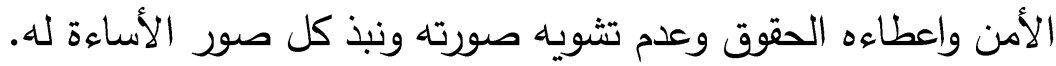

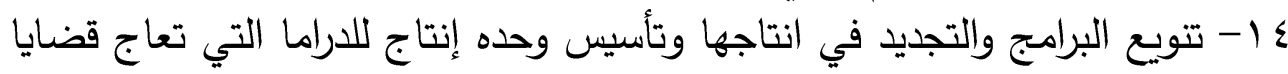

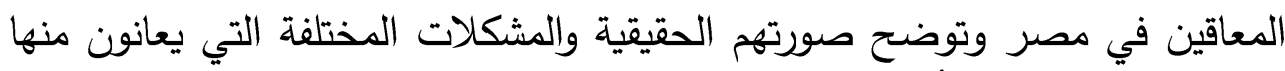
ورصد الجوائز الجيدة لأفضل إنتاج ·

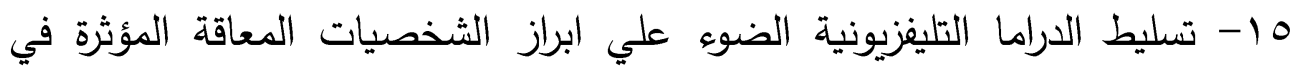

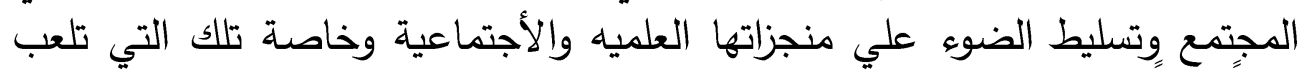

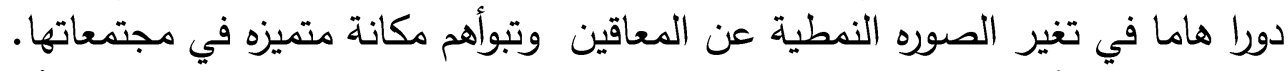

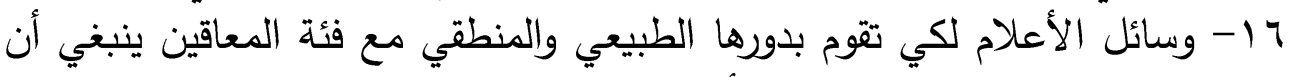

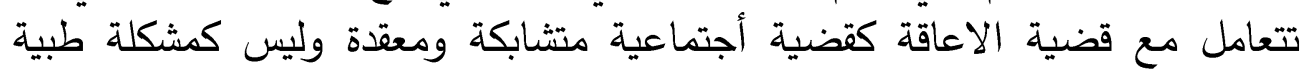

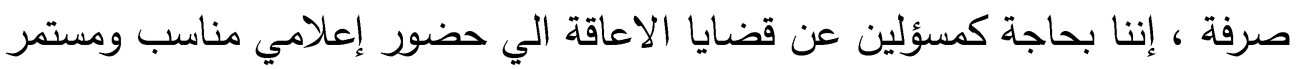


ومتواصل في وسائل الأعلام حتي نستطيع أن نجعل قضايا الأشخاص المعاقين

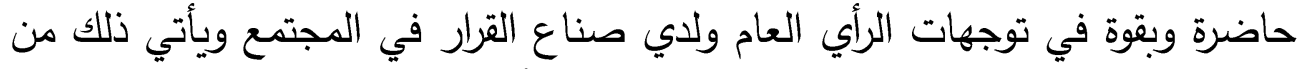

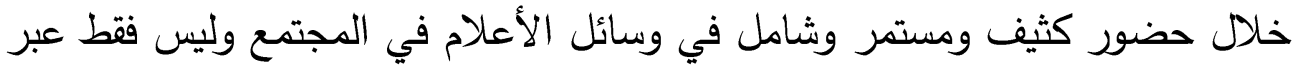

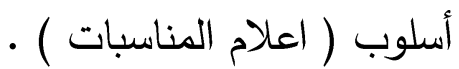

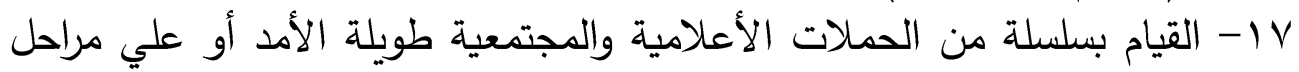
تستهدف تغيير القناعات والقيم والأفكار بالنسبة للأعاقة أو المعاقين ويعرف هذالة الأندا النوع

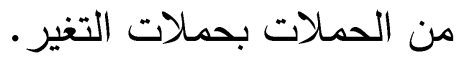

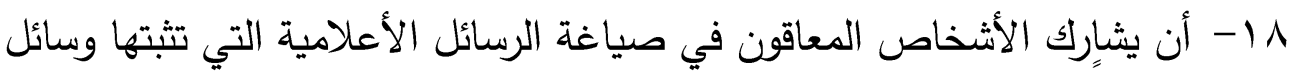

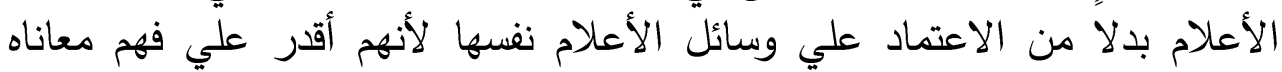

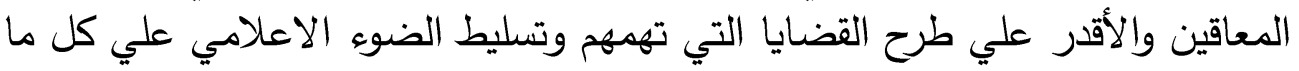

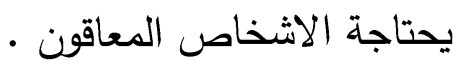

قائمة المراجع العربية والأجنبية

1- Frane kurt cy. ike, uichal m. moodie Robert e fistick , ( serving the bund and phy sically handi capped in the lenited states of amirca ) library trends, sbring 2007 , pp , $796-808$

r- حول حقوق الأط فال ذوي الاحتياجات الخاصة ، مركز حقوق الأطفال ذوي الاحتياجات

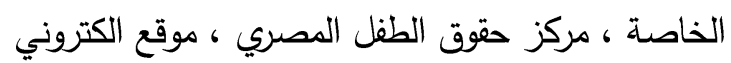
http :/ mbadr. Net / a/ abohabiba/ con ference htm . r- أسماعيل عبد الفتاح السيد ـ التتمية الفكرية والثقافية لذوي الأحتياجات الخاصة ، ط؛ ( مصر

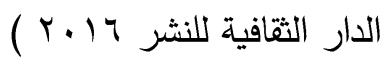
ع- المصري اليوم ، ( الحملات الاعلامية والتوعية من أجل ابراز أهمية ملف الأعاقة وذوي

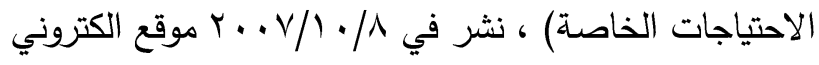
youm.com .http://www.almasry-ai ه- عبد الرحمن عثمان ، دور الاعاقة والتحول نحو المجتمعات المستدامة ( القاهرة : دار

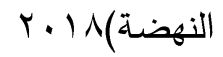

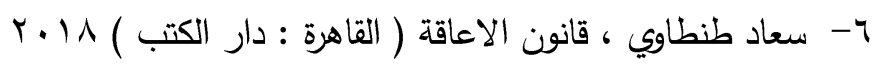
V- سهير صالح ابراهيم : الاحتياجات الاعلامية والتقافية للمعاقين من برامج التادئ التليفزيون ( جامعة

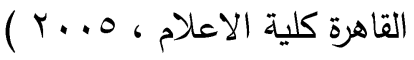
^- فردوس بنت جبريل ، احتياجات المعاقين اعلامياً ومدي اشباع وسائل الأعلام لها ( القاهرة :- .

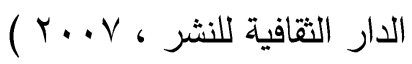
9- علي شويل القرني ، اتجاهات الاعلامين السعودين نحو ذوي الاحتياجات الخاصة دراسة مسحية

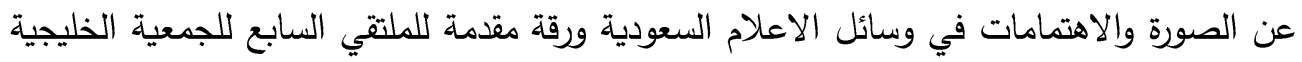

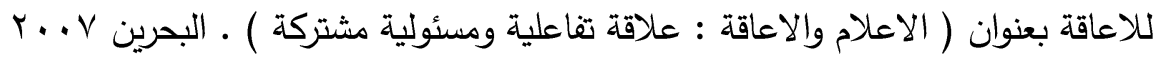


• ا- مروي عبد اللطيف محم عبدالعزيز .( علاقة تعرض الأطفال ذوي الأحتياجات الخاصة

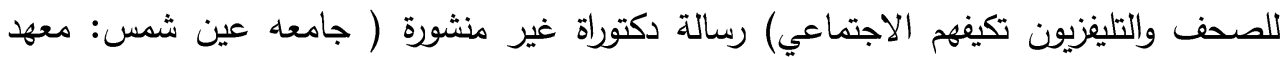

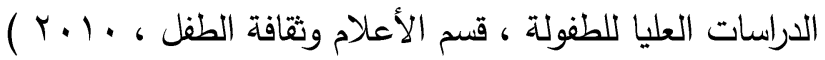

1)- Olan farnall and kim a.smith ( relations topepole with disabilities : persna contact.versus viewing of speci fic media) portra yals ( journalism and mass communication quarterly ) vol.276, no. 4 , winter2013 r ا- حنان يوسف ـ معالجة الأعلام العربي لقضايا الأشخاص ذوي الأعاقة وعلاقتهما بتثكيل اتجاهات الجمهور نحوهم

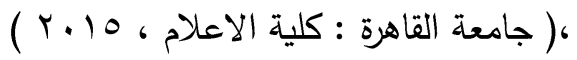

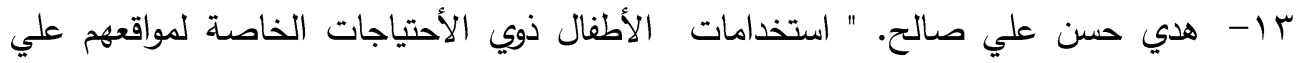
الانترنت والأشباعات المتحققة منها " رساله ماجستير غير منشورة ( جامعاه عين شمس : معهد

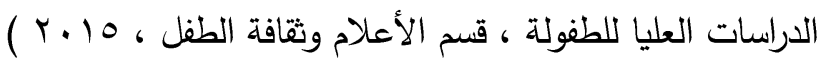

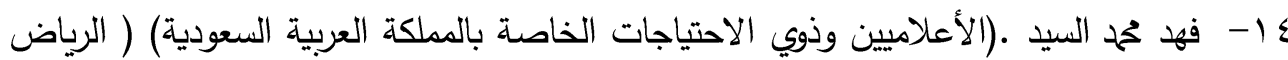

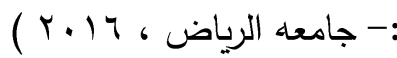
10 - رحاب سعيد أحمد عبد الرحمن .( فاعلية فيلم رسوم متحركة بأستخدام الوسائط المتعددة

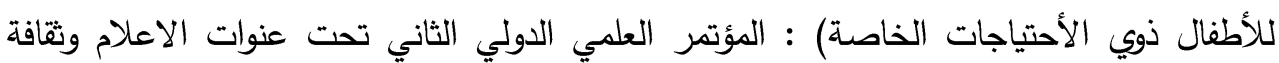

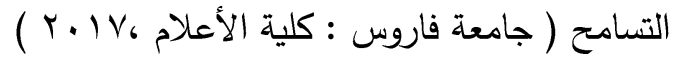

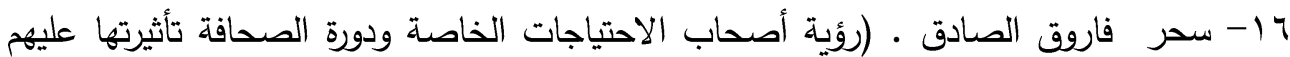

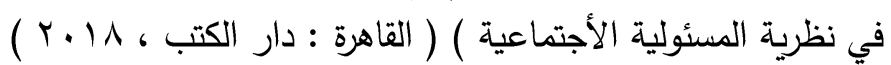

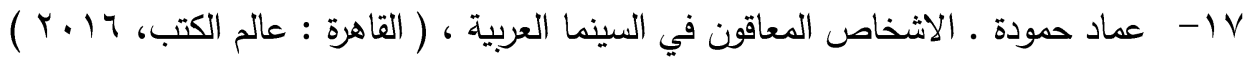

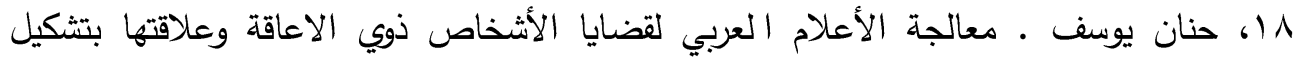

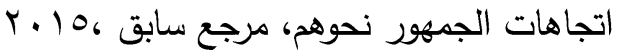

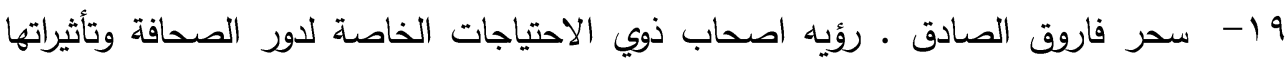

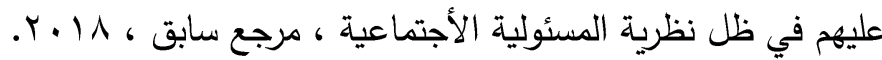

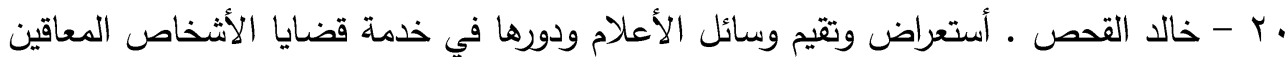

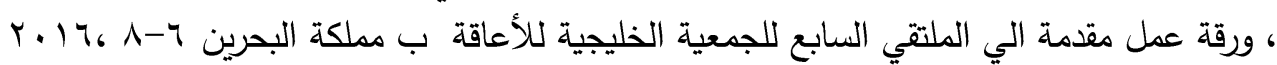

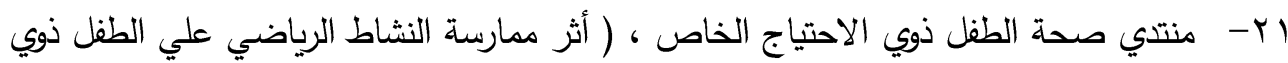

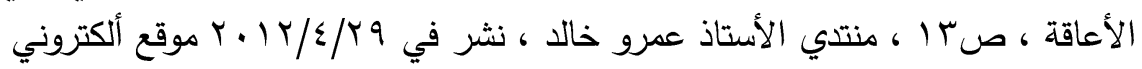

khalad.net www.amr צ r - مني الحديدي ، سلوي إمام • الأعلام والمجتمع ( القاهرة : الدار المصرية ، مكتبة الأسرة ، $\left(r^{\prime} \cdot \varepsilon\right.$ r ب- سحر احمد الخشرمي ـ التغطية الصحفية العربية لقضايا الاعاقة ، اليوم العالمي للمعاقين ،

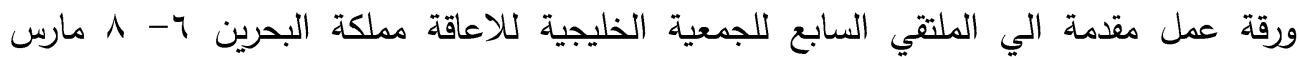
r...V. 
M

ع ז- عدلي سيد رضا ـ البناء الدرامي في الراديوا والتليفزيون ، ( القاهرة : دار الفكر العببي ، - (1911

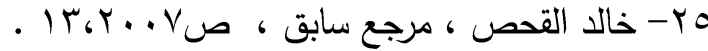

